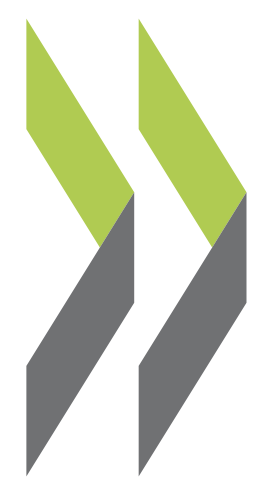

OECD Social, Employment and Migration Working Papers No. 23

\title{
Should We Extend the Role of Private Social Expenditure?
}


Should We Extend the Role of Private Social Expenditure?

Mark Pearson and John P. Martin

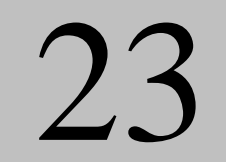


DIRECTORATE FOR EMPLOYMENT, LABOUR AND SOCIAL AFFAIRS

English text only

OECD SOCIAL, EMPLOYMENT AND MIGRATION WORKING PAPERS NO. 23 SHOULD WE EXTEND THE ROLE OF PRIVATE SOCIAL EXPENDITURE?

Mark Pearson and John P. Martin*

* Mark Pearson is Head of the social Policy Division and John P. Martin is Director for Employment, Labour and Social Affairs at the OECD. This paper draws extensively on the work of colleagues. In particular, the analysis in section 2 draws on work of Willem Adema and Maxime Ladaique; section 3 on Thai-Thanh Dang; section 4 on Francesca Colombo; section 5 on Monika Queisser, Pablo Antolin, Alain de Serres and Christine de la Maisonneuve; and section 6 on Manfred Huber and Jens Lundsgaard. We are extremely grateful to them for their assistance. We are also grateful to Martine Durand, Dermot McAleese and Brian Nolan for helpful comments. Mistakes are, of course, the responsibilities of the named authors alone, as are the views expressed in the paper: it commits neither the Organisation nor the governments of OECD Member countries.

JEL Classification: H11, H42, H51, H53, L33.

\section{JT00180761}




\section{SUMMARY}

1. Some people make great claims about the advantages to be gained from greater reliance on the private sector for the provision of social protection. Many of the claims for great macroeconomic advantages do not stand up to scrutiny. However, there is some reason to hope that private provision might promote microeconomic efficiency and services which are more responsive to consumer preferences than those provided by a single monopoly public sector provider. Drawing on examples from recent OECD country experiences with private health insurance, care for children and the elderly, and private pension provision, three main conclusions can be drawn. First, opening provision to a diversity of providers has often promoted more choice and innovation. Second, however, efficiency gains have often been limited. This is due to a number of inter-related reasons: (a) Individualisation of packages of services is expensive. (b) In order to ensure adequate coverage of the population, cross-subsidisation of particular groups of people is often mandated on providers, reducing cost-competition and diversity of choice. (c) Informational asymmetries (how good is this childcare which I cannot personally monitor, or this health care package which I am not technically able to assess?) cannot be overcome without extensive regulation, which has the effect of limiting innovation and competition. (d) The fiscal incentives necessary to stimulate private provision are high, and have welfare costs of their own. Third, and related to this last point, the distributional effects of private provision raise significant social problems. Private financing and provision of social benefits is not a magic wand; waving it in the social protection field will not mean that the economy and voters will be freed from some great deadweight that has been dragging them down. Nevertheless, the private sector can sometimes deliver either a slightly cheaper, slightly more varied or slightly more flexible system of social protection. 
DELSA/ELSA/WD/SEM(2005)2

\section{RESUME}

2. Certains font grand cas de l'intérêt qu'il y aurait au plan macroéconomique à faire davantage appel au secteur privé pour assurer la protection sociale. Les arguments présentés dans ce sens ne tiennent souvent pas la route ; cependant, on peut penser que le recours au secteur privé permettrait peut-être une meilleure efficience microéconomique et une réponse plus adaptée aux choix des consommateurs que ce que peut offrir un prestataire public en situation de monopole. A partir de quelques expériences récentes de pays de l'OCDE en matière d'offre privée pour l'assurance maladie, la garde des enfants, les soins aux personnes âgées et la retraite, trois conclusions se dégagent. Premièrement, la diversification des prestataires a souvent permis un plus grand choix et plus d'innovation. Deuxièmement, cependant, les gains d'efficience ont souvent été limités, et ceci pour un certain nombre de raisons difficiles à dissocier : (a) l'individualisation du panier de prestations est coûteuse ; (b) pour assurer une couverture suffisante de la population, on impose souvent aux prestataires la prise en charge de catégories spécifiques par une mutualisation des coûts, ce qui réduit la concurrence au niveau des prix et par conséquent la diversité de choix ; (c) l'asymétrie de l'information (quelle est la qualité de ce dispositif de garde des enfants sur lequel je n'ai aucun contrôle ou de ce panier de soins que je ne suis pas techniquement capable d'évaluer ?) ne peut être surmontée sans un encadrement réglementaire précis, qui a pour effet de limiter l'innovation et la concurrence ; (d) le niveau des incitations fiscales nécessaires pour stimuler l'offre privée est élevé et a un coût au niveau de l'intérêt général. Troisièmement, en rapport avec ce dernier point, les effets distributifs d'une protection sociale privée posent des problèmes importants au plan social. Le financement et la fourniture de prestations sociales par le secteur privé n'est pas une solution magique ; l'appliquer dans le domaine de la protection sociale ne veut pas dire que l'économie et les citoyens se trouveront délivrés d'un lourd poids mort. Il reste cependant que le secteur privé peut parfois offrir un système de protection sociale un peu moins cher, un peu plus diversifié ou un peu plus souple. 
TABLE OF CONTENTS

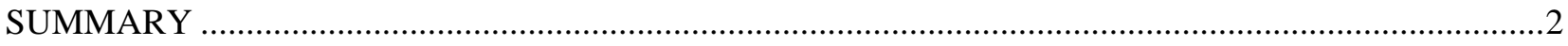

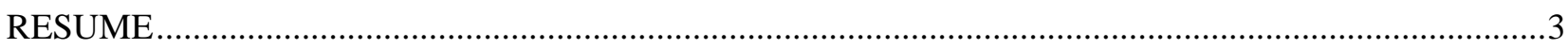

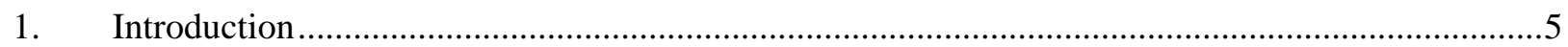

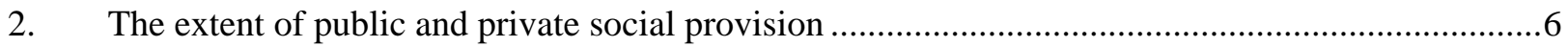

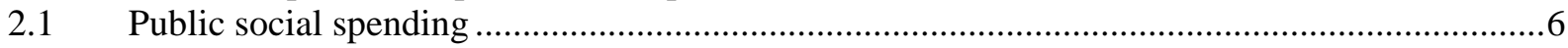

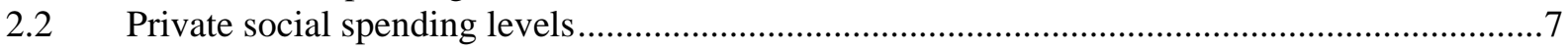

3. The theoretical case for and against more private social spending ….............................................

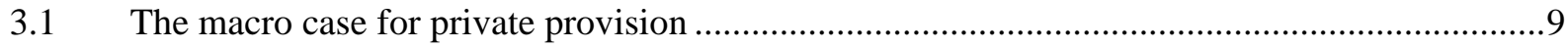

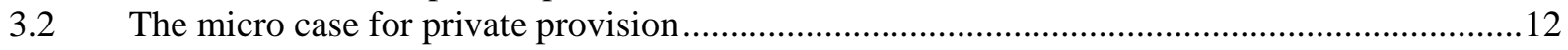

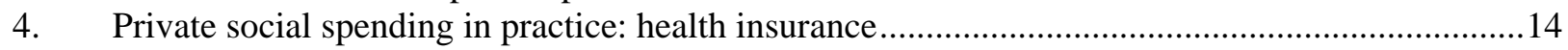

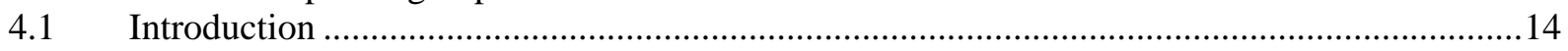

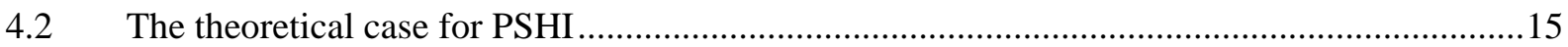

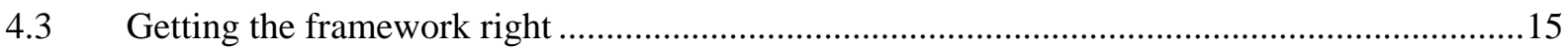

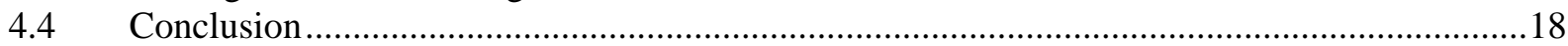

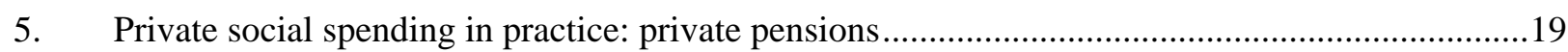

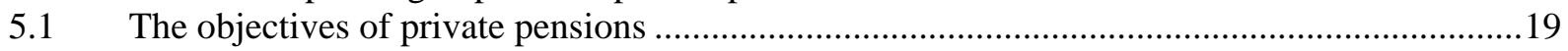

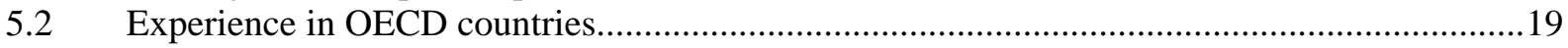

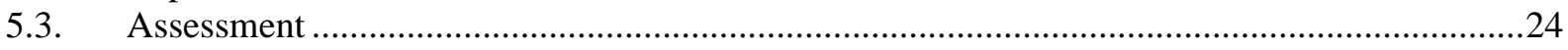

6. Private social spending in practice: care provision for children and the frail elderly ....................24

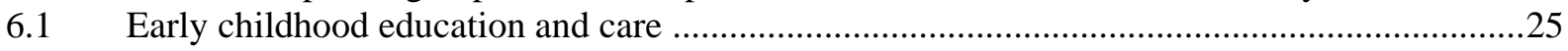

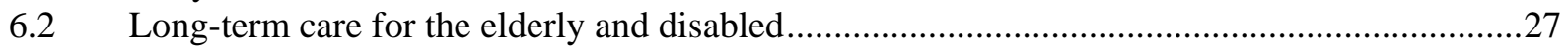

6.3 Assessment of outcomes from competition and user choice in care services.............................29

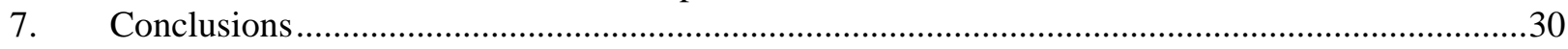

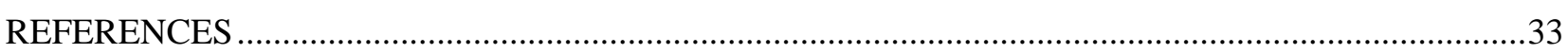




\section{Introduction}

3. Public expenditure is $43 \%$ of GDP on average across the OECD (Chart 1). Regardless of overall spending levels, social spending constitutes over half of public spending in almost all countries other than Japan where the proportion is about one third. Small wonder that people question whether social spending needs to be this high. One option is to cut social spending, but this is unpopular, and indeed may be undesirable in many circumstances. However, following the example of privatisation of many public sector activities over the past two decades, some argue that part of social spending could be undertaken privately. The proponents argue that not only would this permit a reduction in too-high tax burdens, but it could well result in better and more cost-effective social outcomes. Others dispute the likelihood of such positive outcomes.

\section{Chart 1: Social spending accounts for almost half of total public spending}

Social and other public expenditure, in percentage of GDP, in 2001

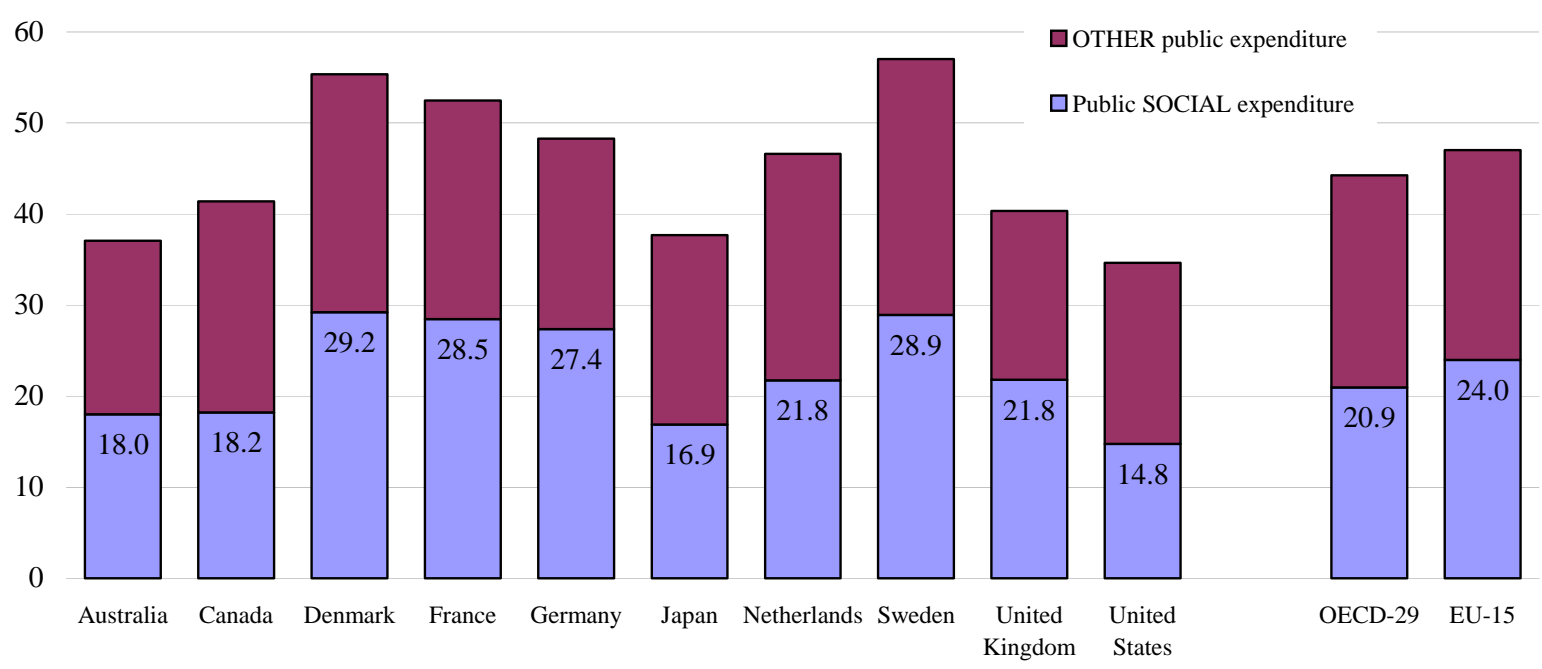

Sources: Estimates based on OECD (2004 and 2004a).

4. This paper assesses whether there is a good case for relying on the private sector to be responsible for more of those social expenditures which are currently undertaken publicly. It first describes the current extent of social spending in different countries. Based on recent OECD studies, the paper then assesses the various claims that have been made as to the advantages of private social expenditures. The main body of the paper looks in more detail at the practical experiences of private social spending in three main areas: (i) health insurance; (ii) provision of income in retirement; and (iii) child care and long-term care for the elderly. Of course, there are many other areas which could have been chosen: sickness and disability, health care delivery, delivery of employment services, etc. The three areas of focus in this paper were chosen for four main reasons: first, the intrinsic importance (for example, in terms of financial flows) of health insurance and retirement income provision; secondly because some countries have experimented with greater private provision in these three areas; thirdly, they cover both financing of social protection (health, retirement income) and delivery of services (child care and long-term care); and finally, we have at our disposal recent OECD studies of private provision in all three areas. The final part of the paper distils some policy conclusions. 


\section{The extent of public and private social provision}

\subsection{Public social spending ${ }^{1}$}

5. Public social expenditure doubled in nearly all OECD countries between 1960 and 1980, as social insurance schemes (particularly for old-age pensions) matured and countries extended provisions, particularly in the area of sickness and disability. In the aftermath of the second oil price shock and the global recession of the early 1980s, social spending declined somewhat to remain fairly stable during the rest of the 1980s (Chart 2) gives. With the economic downturn in the beginning of the 1990s in most OECD countries, the public social spending effort shot up again, especially in Finland and Sweden (trends in Germany are influenced by re-unification). Strong economic growth during the second half of the 1990s contributed to a decline in public social spending as a percentage of GDP in most countries except Japan. On average, public social spending accounted for 21\% of GDP for the OECD area and $24 \%$ for the EU (OECD, 2004) at the end of the 1990s.

\section{Chart 2: Overall increase in public social expenditure from 1980 to 2001}

Public social spending, in percentage of GDP, 1980 to 2001

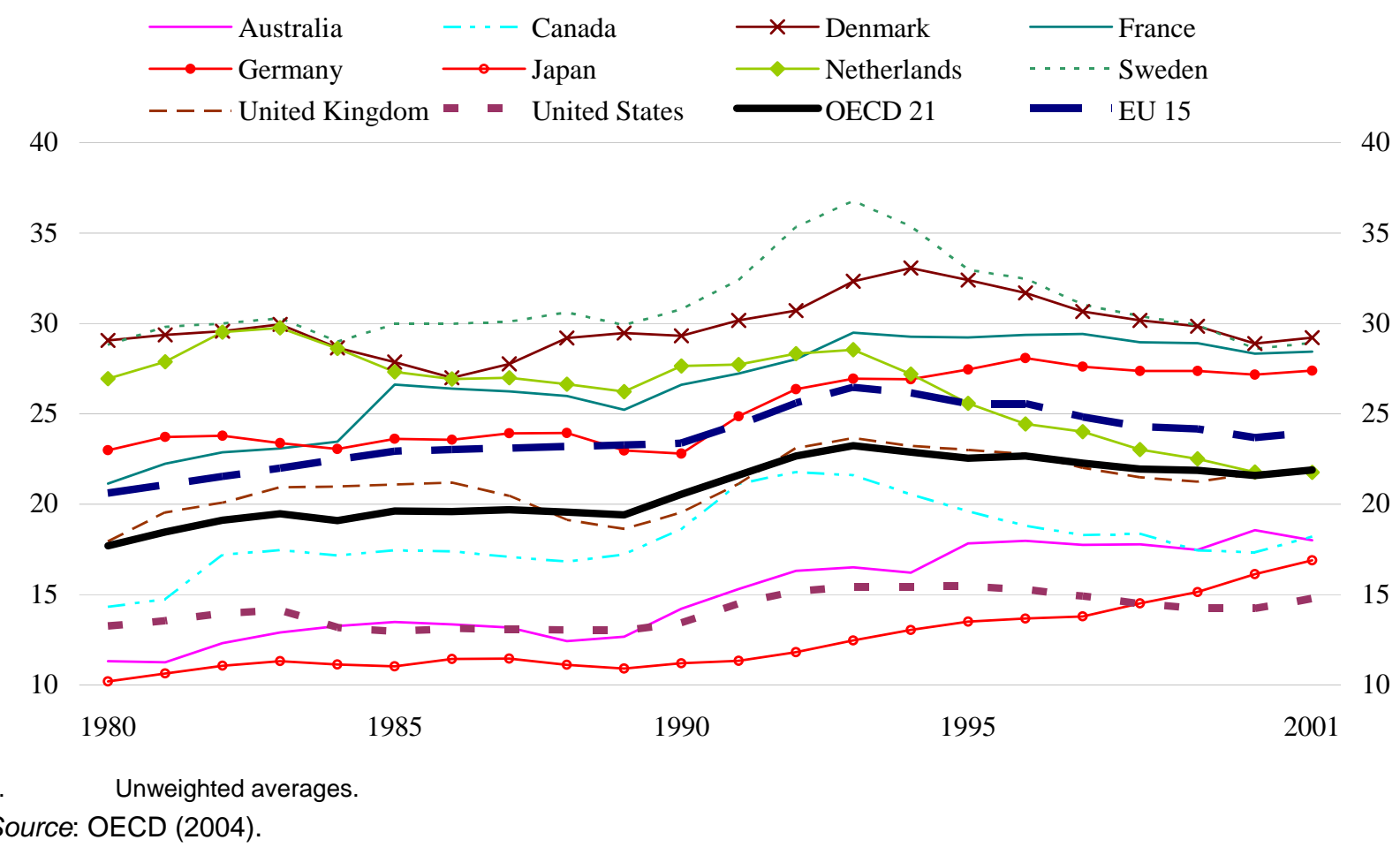

6. Across the OECD area, demographic trends will exert upward pressure on public spending. Indeed, OECD estimates suggest that increases in spending on old-age pensions and health will amount to

1. Public social spending includes all government expenditure on income transfers and social services. 'Government' includes both central and local government, and also those bodies such as social insurance funds which are formally separate from government, but which in practice are controlled by tight government regulation. SNA93 guidelines are followed in these cases. Income transfers include old-age pensions, disability, unemployment and social assistance benefits, family payments, and earnings supplements. Services include health, child care and long-term care services. A full definition can be found in OECD (2004 and 2001). 
over 5\% of GDP on average over the next few decades, even after taking into account the likelihood that declining birth rates will lead to lower public spending on family benefits and education (OECD, 2001d).

7. The sustained economic upswing contributed to the stabilisation of the ratio of public spending to GDP in the latter half of the 1990s. But social policy reform also appears to have played a role. This is shown most dramatically in the Netherlands where the public social spending effort at the end of the 1990s was below its 1980s level. In the beginning of the 1990s, access to some public benefit programmes was restricted while some benefits were reduced, or grew by less than the rate of inflation (OECD, 1999 and Kalisch et al., 1998). But a key element was a move towards greater private provision of social benefits: in the mid-1990s, the Dutch government increased employer responsibility for payments to employees who are absent from work because of sickness. As a result, social spending on incapacity benefits is now $3 \%$ of GDP below its 1980 level.

\section{$2.2 \quad$ Private social spending levels}

8. By private social spending is meant those expenditures for social purposes - to help individuals and families cope with sickness, joblessness, old age etc - which are undertaken by private individuals, companies or NGOs, rather than through government agencies funded by taxes or social insurance contributions. $^{2}$ Such private expenditures might be mandatory (the government legally requires such behaviour) or voluntary (the government does not require the behaviour as such, though it may well encourage it through tax reliefs or other subsidies).

\section{Chart 3: Private spending accounts for $\mathbf{4 \%}$ (in Denmark, Finland) to $\mathbf{4 0 \%}$ (in the US) of total social spending}

Public, mandatory and voluntary private social spending, 2001, in percentage of GDP

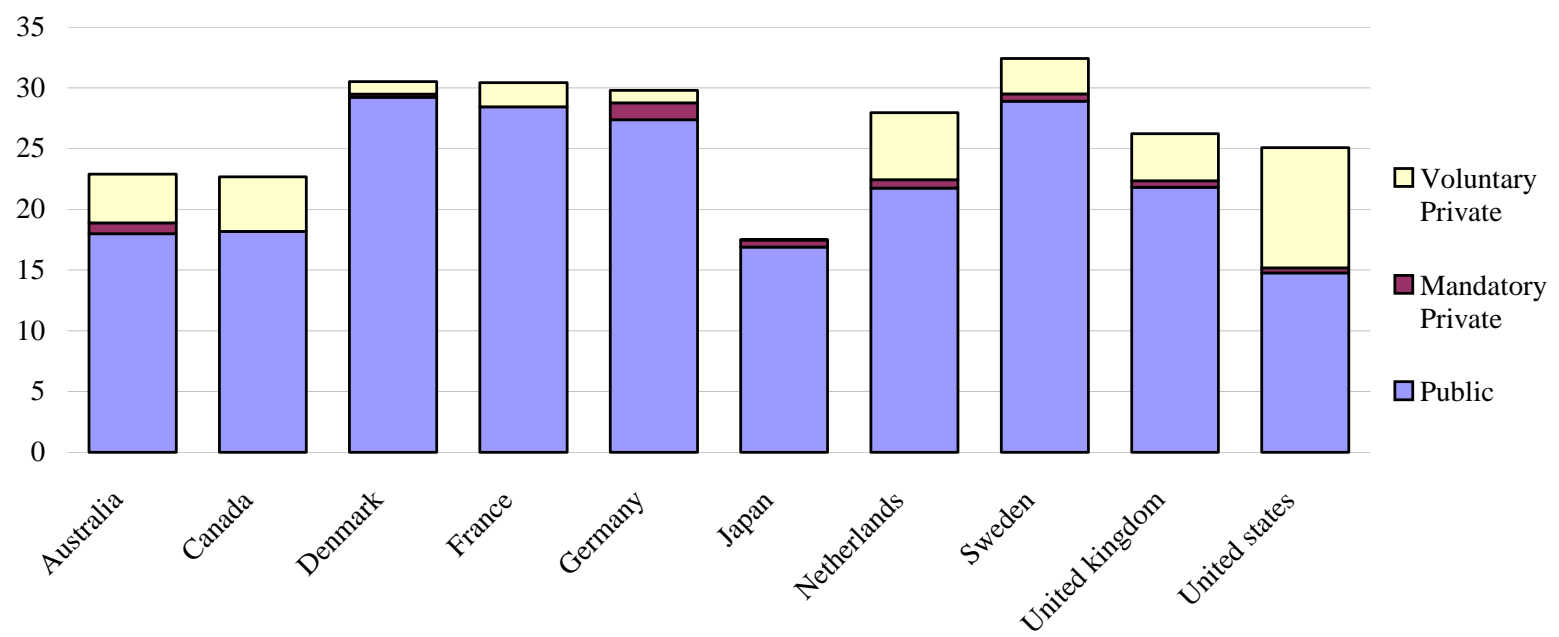

1. In contrast to the other countries, voluntary private social spending in Sweden includes benefits paid to retired civil servants, and available information on total spending by relevant private funds does not allow separate identification of total spending on civil servant pensions. In the Netherlands, the fund managing civil servant pensions has also been privatised recently, which would further raise private spending levels. Notwithstanding this development which is reflected in the national accounts methodology, pension payments to civil servants remain a public liability.

Sources: Adema and Ladaique (2005).

9. As the Dutch example above suggests, mandatory private social benefits often concern incapacity-related benefits - sickness, disability and occupational injury benefits; they exist in Germany,

2. See Adema (2001) for a more rigorous discussion of the definition and borderline cases. 
the Netherlands, the UK, and parts of the US, while in Denmark and Sweden employer payments top up existing public benefits. Mandatory private social benefits are also found in retirement income provision, with mandatory pension contributions to employer-based and/or individual pension plans, as in Finland, Japan, and the United Kingdom. Chart 3 shows that spending on mandatory benefits ranges from about 0.5 to $1 \%$ of GDP, and is largest in Germany, where there is no public reimbursement of employer sick-pay and benefits are relatively generous.

10. Voluntary private social benefits are most often found in countries where public provision is limited. Pension benefits constitute a major component of voluntary private social benefits everywhere, but are most important in countries where generosity of public pension benefits is comparatively limited. Thus, it is not surprising that private pension benefits are most important in the Netherlands, the UK and the US where relevant spending exceeded 3\% of GDP in 1997, compared with 2\% in Sweden (see note to Chart 3), almost 1\% in Denmark, Finland and Germany and less than 0.5\% of GDP in Japan (Adema, 2001). These figures do not, however, fully reflect the importance of private pension programmes. They refer to the benefits paid under such programmes, but many of them are quite immature. Current contributions exceed the magnitude of current benefits significantly in most countries. Hence, the importance of these private pension benefits is expected to grow in the future with the maturing of pension plans.

11. In the absence of a public health insurance system with universal coverage for workers, private health spending is most important in the US: employer-provided health benefits to their workers, dependents and retirees was estimated at over $\$ 440$ billion in 2004 (equivalent to over 4\% of GDP) - these expenditures do not include payments by individuals for health services (see section 4).

12. Other examples of private social benefits include: supplementary unemployment compensation in the US, employer-provided childcare support in the Netherlands and employer payments during parental leave periods in most countries. Moreover, in line with collective agreements, employers in most European countries often top-up incapacity-related public and/or mandatory benefits to give replacement rates of $100 \% .^{3}$

13. Chart 3 shows that most social support is publicly provided. In most European countries, the share of public social spending in total social expenditure is around $95 \%$, while this proportion is about $85 \%$ in the Netherlands and the UK. At about $8 \%$ of GDP, private social spending is most important in the US, where it constitutes about one-third of all social spending.

14. Private social expenditures have increased since 1990 (Chart 4), but with the exceptions of the Netherlands and the United States, the increases have been small. The following sections discuss the reasons which have motivated reforms promoting greater private provision of social benefits.

3. Non-governmental organisations (NGOs) also provide important social support. However, comprehensive data on employer benefits for social services provided by NGOs that is comparable with the detailed information in the OECD Social Expenditure Database is not available, except for a few countries. For example, in Sweden the value of private social services amounted to 0.4\% of GDP in 1997 


\section{Chart 4: Private social spending has increased since 1990}

Mandatory and voluntary private social spending, in percentage of GDP, 1980 to 2001
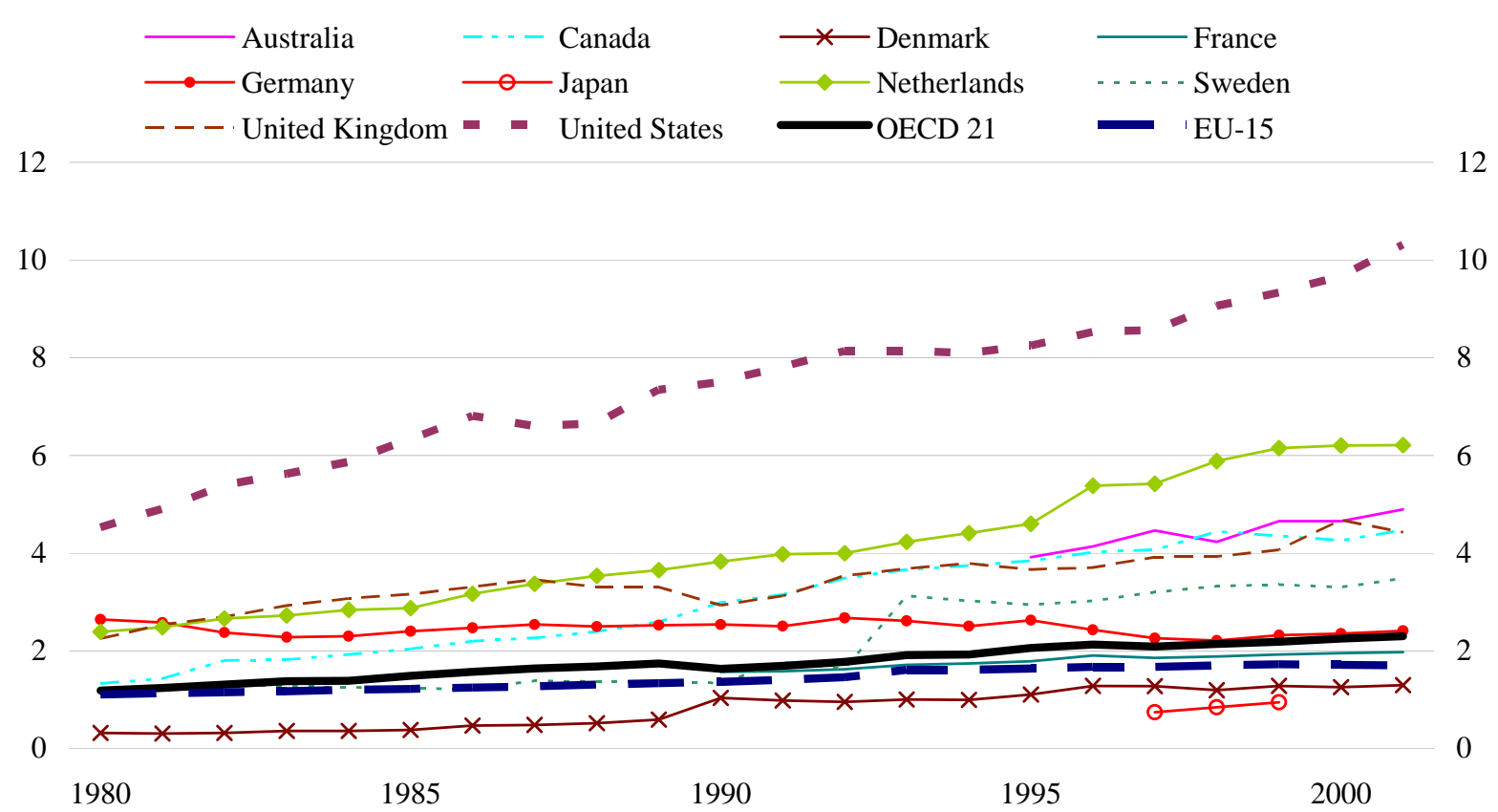

1. Break in Swedish series after 1992 when information on employer-provided sickness payments and private social services becomes available.

Source: Adema and Ladaique (2005).

\section{The theoretical case for and against more private social spending}

15. Everyone is aware of the disastrous outcomes of some privatisations, which have led to scandals such as Enron in the United States, or Railtrack in the United Kingdom. Still, many policies of privatisation and deregulation in energy, telecommunications and (certain) transport sectors have been moderately successful (e.g., see the case studies presented in OECD, 2001e). This has encouraged policy makers to look for additional areas where such reforms may yield benefits. It is only natural that their attention has turned to the provision of social spending. However, debates around private provision in the area of social expenditures have been somewhat confusing.

16. For example, is the goal of private rather than public provision to lead to greater economic efficiency in delivering a given package of services, or is it is to give individuals more choice over the package of services on offer, or to promote fiscal savings etc? The various cases which might be made in favour of greater private provision are considered in this section.

\subsection{The macro case for private provision}

17. One group of arguments for making greater use of the private sector in financing and delivering social protection is that the result will be a more efficient economy. 
a) Greater use of the private sector leads to a smaller welfare state. This, in turn, means lower taxes, and lower taxes mean a more efficient economy.

18. There is some evidence that higher taxation is associated with lower growth (e.g., Bassanini and Scarpetta, 2001; Arjona, Ladaique and Pearson, 2001). However, if all that happens is that exactly the same scheme and level of provision is transferred from the public to the private sector, someone is paying (either in taxes or user charges) and someone is receiving the benefit. It is hard to see why an accounting convention about what social spending goes through the public accounts should make a real difference to economic outcomes.

b) Help in getting the level of provision right.

19. Given the current structure of financing of social protection in many countries, there is a lack of transparency as to the costs of social protection borne by individuals. In social insurance systems, the value of the contributions of individuals rarely matches the future benefits they can expect to receive. Instead, employers also contribute, or else 'government' (i.e., taxpayers) funds the deficit. The temptation is for workers to see only their employee contributions as being the costs to them, so increasing social provision via employer contributions looks an attractive alternative. But it only looks relatively attractive: in practice, employers' social contributions are incident on their employees' wages, and this goes for most sources of taxation as well. In other words, by confusing individuals about the true costs of programmes, there may be an in-built bias in some systems towards expanding social programmes beyond their optimal size. Of course, at the macro level, this implies a higher tax wedge which can damage employment and output.

20. Governments have involved the private sector in financing social protection because they believe that this will help make the true costs and benefits of a programme more transparent to those involved. For example, in the mid-1990s in the Netherlands, the provision of sickness benefits was moved from a social insurance scheme to being the responsibility of employers. Dutch private insurers who initially set premiums at relatively low levels quickly found it necessary to increase sharply their premiums, and employers have begun to try to minimise claims on the system as a result. ${ }^{4}$

21. However, there are some obvious ways of increasing the transparency of the system whilst still maintaining a publicly-financed and managed programme. Again in the Netherlands, the 'Oort reforms' of 1990 shifted responsibility for social insurance payments from employers to employees, at the same time as raising gross wages to compensate workers, in order to be able to demonstrate to workers via the pay packet the true costs of social programmes.

c) Use of the private sector will lead to greater flows through financial markets, with economy-wide payoffs.

22. Greater use of private alternatives to public provision of social protection very often involves greater use of financial markets which will increase the pool of saving available for investment. Private health insurance leads to greater funds going to insurance companies who then seek to diversify their risk through purchasing other assets. Private pension provision usually involves funds being invested in the financial markets by or on behalf of the individual or the company concerned.

4. Making the costs of a programme transparent is not always straightforward. When employers are made responsible for the insurance of their workers, no doubt they do become more cost aware. However, they may try to shift the cost onto employees, for example by choosing insurance polices with greater costsharing. 
23. This could have beneficial economy-wide benefits under two circumstances. First, the greater flows through financial markets will increase the pool of saving available for investment. Some influential economists have argued that the rate of return on equity investments can be high: for example, Feldstein (1998) takes a benchmark figure of 5.5\% after inflation. This is significantly higher than current potential growth rates. The implication of such high rates of return is that if more savings were channelled to capital markets by, for example, reducing public provision of pensions and requiring individuals (or companies, on behalf of individuals) to save for their own retirement, investment would increase and growth rates would rise accordingly.

24. However, there are counter-arguments to this school of thought. Most obviously, many take issue with the very high rates of return which are assumed. Even were these very high rates of return to be accepted as valid in the short run, this does not mean that any individual investment portfolio could offer such a high rate of return. By diversifying investments, risks could be reduced, but only at the cost of reducing expected returns - and therefore the case for privatising pensions becomes correspondingly less compelling. Furthermore, there are additional administrative costs to privatising pensions, particularly if this is done through individual accounts (see below) and these can sharply reduce the potential gains.

25. The second reason why there might be economy-wide benefits from moving to private provision of pensions is that any given amount of investment may be done with more efficiency (because the financial markets, being larger, will have greater ability to bring specialist knowledge to bear on individual investment decisions), but also because of the type of investment (e.g., private pension funds are more likely to invest in risky investments that will spur innovation and growth).

26. Recent OECD work suggests that there is some evidence in support of both of these possible effects (e.g., Leahy et al., 2002). However, there is also evidence that such effects can only be realised in an appropriate regulatory framework. It is self-evident that, to take a topical example, the investing of most of the private pension contributions (in 401(k) accounts) of Enron employees in the stock of Enron itself contributed nothing worthwhile to the development of financial markets in the United States. Indeed, more generally, OECD countries do not have a great record in getting the regulatory framework right for private pensions (see below).

d) Private provision can have the desirable effect of pre-funding social programmes, reducing the impact of ageing populations on the economy.

27. Greater use of private provision of social benefits is often talked about as a way of increasing savings and building up assets to cope with future contingencies - population ageing, for example. This is particularly important for retirement income provision, for example, but similar arguments can be used for individual health saving accounts. The idea of building up assets is a sensible objective. However, unless pre-funding involves investment abroad (which is politically difficult for many countries to consider), ultimately the retired population consumes goods and services which are produced by the working population, and no amount of pension reform can change this. Pre-funding is nevertheless sensible - as a way of smoothing the lifetime consumption of contributing cohorts of the population, and ensuring that subsequent populations have higher productivity out of which to fund future retirement incomes.

28. Although the objective of smoothing lifetime consumption faced with ageing populations is a good one (see, e.g., OECD 2001a), private sector retirement income provision is again only one means to the end. For example, it is possible to run a public pension system which builds up assets when the demographic conditions permit, either generating assets which can be sold when the scheme moves into deficit or reducing the public sector debt, so reducing future tax payments needed to service the debt. In Ireland, for example, $1 \%$ of GDP must be 'saved' annually by the public sector against future pension 
liabilities. That said, there are good reasons why many experts believe that pre-funding would be better left to the private sector. For example, governments may pursue other objectives than the highest rate of return from public sector investments. Experience suggests that governments will often succumb to pressure to invest in 'social' investments, where rates of return may be significantly below that which the private sector could achieve.

\subsection{The micro case for private provision}

29. There may be macro-economic benefits from private provision of social protection, but often the benefits are not intrinsic to private control of social expenditures per se: rather, greater use of the private sector is one means to an end which might be achieved through other policy instruments. However, there are theoretical objections to the private sector being involved in providing social services, namely, that the very nature of the services in question makes private provision unsuitable.

30. One view of social protection is that it is a public good (or at least, some elements of social protection are public goods). If private individuals (or companies) were to decide how much to spend on such goods, they would take into account only their own private interests. For example, in addition to the private benefits from childcare accruing to the parents and children directly affected, there might be benefits to society as a whole if child development outcomes improve. People who only take into account their private interests might, to take another example, not get medical coverage against communicable diseases, leading to an increase in general morbidity. They might also attempt to free-ride on the goodwill of others: most people object to seeing old people in poverty, or sick people going untreated, so provide them with help even though they could and should have had the foresight to have saved for their retirement, or to have taken out health insurance.

31. A separate issue is that of 'informational asymmetries'. As a parent, I wish to have the best possible childcare for my children, and high-quality healthcare for all my family. Were the private sector to provide such services, I may have no way of telling whether I receive what I want, because it would involve an unrealistic amount of time and effort on my part to get the necessary information. Traditionally, the welfare state has offered a way around this problem: it promises to act in the public interest in ensuring that a quality service is provided. The private sector (with its concern about cutting costs so as to maximise profits) may not have the same incentive to offer a quality service.

32. These are important problems. However, whilst the externalities of some social provisions and the informational asymmetries associated with others certainly justify public interest in the nature of social provisions, the consequences for whether finance and delivery of social protection should be public or private are far less clear-cut. Ensuring that communicable diseases are treated, or that old people have resources in retirement, could be achieved by mandating individuals or companies to take out appropriate medical insurance and make sufficient provision for old age. Even with the example of childcare, where it is difficult to envisage a similar solution, the case for public subsidy may be clear, but the case for direct public provision (as opposed to subsidising private provision) is not.

33. Even in the presence of informational asymmetries, the case for public provision cannot be accepted without qualification. Sometimes public services can become moribund and lacking in public spirit. Regulations on the sort of services which the private sector should provide, with verification procedures, might be as effective as direct public provision.

34. It is, therefore, difficult in purely theoretical terms to make a strong case that most social spending should be either public or private. It is rather an empirical question, which hinges around whether it is possible to design a regulatory package which both meets the legitimate public interest in social 
protection, but also encourages those aspects of private sector behaviour which might encourage greater efficiency in service delivery. Just what these efficiency gains might be is a question which itself is often very confused, because some of the perceived gains from using private as opposed to public provision are nothing of the sort: they are gains from moving away from 'traditional' socialised provision - how the schemes are structured and run, not who owns them. For example:

- Individualisation. Private insurers provide individuals with choice over e.g., the level of coverage, through operating individual accounts to insure individual risks rather than pooling risks across a population. Individualisation of some sort probably is both desirable and inevitable. People do differ in their preferences, and forcing them to accept a 'one-size-fits all' social insurance is inefficient. The failure to provide what people want leads to them being less supportive of social protection. However, although this is a problem with many systems of public social protection, it is not intrinsically connected with public or private sector provision. It is possible to let public provision of social protection reflect diversity, by tailoring benefits to individual circumstances. ${ }^{5}$ Regardless of who provides individualised services, however, there are two factors which have to be weighed against possible efficiency gains. The first is that the burden of managing the individual schemes can be high (see the discussion of private health insurance and pensions below). The second is that, if schemes fully reflect the circumstances of individuals, there is no scope for ex-ante redistribution. Most social programmes have ex-ante redistributive goals, even if the ex-post outcomes do not always match them.

- Diversification. Diversification means the possibility to widen the range of investment risks to secure asset returns and reflect individual's preferences towards risks. This can be made by individuals in their private social security accounts, who may either determine or simply influence the sort of assets in which their savings are invested. Spreading risks is desirable; for example, relying on publicly-provided pay-as-you-go (PAYG) pensions is in effect betting on future generations honouring a system about which they could not be consulted. But equally it is possible to imagine a publicly-run social security fund moving away from total reliance on contributions based on labour income in a PAYG system - many publiclyoperated social security funds do so already (e.g., in Norway and Korea).

35. Hence, greater use of the private sector might be associated with achieving certain aims (e.g., ensuring pre-funding or getting the level of provision right) but such goals could also be achieved in a reformed public system. There are some arguments, however, which do refer to genuine advantages of private sector provision over public provision:

- Flexibility of products and practice. The public sector is not, as a matter of fact, very good at promoting innovation and novelty. Much of the case for privatisation in other areas has been based on the argument that it would free managers from government interference. Governments are, intrinsically, risk-averse, while innovation inevitably comes with a risk of failure, and policy failure is something that politicians dislike. Governments have tried to insulate ministers from public criticism over these issues by creating arms-length agencies, responsible either for providing the goods and services in question or regulating the

5. Of course, ending the pooling of risks has potential distributional consequences (though given the limited redistributive nature of some public contributory programmes, this can be exaggerated). Policy has avoided individual choice in many social areas for good reasons - myopia (people make bad decisions - e.g., not saving enough for their pension), informational asymmetries (individuals can hide from insurers their true intentions as regards e.g., finding a job), or consequences for third parties (i.e. we may be prepared to let adults cope with the consequences of bad choices, but society is reluctant to let children suffer). 
providers. However, the track record of many of these arms-length agencies leaves much to be desired.

- Efficiency in administration. The profit motive is a powerful tool to cut costs. Of course, some forms of cost-cutting are inappropriate. If people are genuinely entitled to a benefit, they should receive it. As discussed below, very careful regulation may be necessary to make private provision feasible. Also, the case for using the private sector as a means of cutting costs has to take into account the fact that the public service ethos means that wages in the public sector may sometimes be lower than in the private sector and spend more on marketing, leading to waste. Turning public provision into 'just another business' may lead to pressure to raise wages. Still, administrative gains are a possibility, not least because costs will become more transparent to users.

36. In sum, while it is rather easy to outline theories under which private provision of social benefits could lead to efficiency and welfare gains for individuals and societies, there is nothing inevitable about positive outcomes. Public sector provision is not always second-best. One has to assess the specific circumstances of each country and the component of social protection in question. Happily, there are many illustrative examples to guide us. Subsequent sections move away from theory and, drawing on recent OECD analyses, look at the experiences in three important areas of social protection: the financing of health care; the financing of pensions; and the provision of childcare and long-term care.

\section{Private social spending in practice: health insurance}

\subsection{Introduction}

37. In some countries including Australia, Ireland, the Netherlands, Switzerland and the United States, private health insurance $(\mathrm{PHI})^{6}$ constitutes one main pillar of the health system, representing the object of explicit public policy interventions. Regulation in such cases extends beyond financial solvency to encompass controls to promote cross-subsidisation across individuals of different risk profiles. Moreover, incentives are established to stimulate individuals to take up PHI, usually through the tax system. Market penetration is high as a consequence. In another group of (e.g., the United Kingdom, Italy, Spain and most Nordic countries), the role of private financing is minor and the PHI market is neither stimulated nor regulated explicitly. ${ }^{7}$

38. As Table 1 shows, private health insurance has different roles in different countries. In some countries, PHI duplicates the services of a public system, perhaps offering a way to avoid waiting lists or to have a more personalised service, but not to provide a different service. In others, the role is to supplement public provision of basic health services with additional elective services, including dentistry, for example. In France, the role of PHI is to insure individuals against high out of pocket payments. Only in the United States and for those taking out private provision in Germany and the Netherlands is PHI for primary health care.

6. Private health insurance includes health financing arrangements characterised by pre-payment of health cost and the pooling of revenues so that the risk of having to pay for health care is borne by all members of the pool and not by each contributor individually. The main source of finances for PHI is constituted by non-income-related premia, as opposed to public health insurance that is financed through general taxation or payroll levies. Premia represent the private payments that a policyholder agrees to make for an insurance policy.

7. Employers often provide group access to private health insurance for their employees as a fringe benefit. This may take place in both groups of countries, and this paper does not directly discuss the implications. 
39. Public policy arguments employed to support a larger involvement of the private health insurance industry in financing health care range from relieving cost pressures on public health systems, to improving individual choice and providing more responsive and innovative care. This section explores some of the existing evidence on whether these aims have been achieved or not.

Table 1: The role and coverage of private health insurance

\begin{tabular}{llll}
\hline & $\begin{array}{l}\text { Private health insurance } \\
\text { as a share of total health } \\
\text { expenditures }\end{array}$ & Population Covered & $\begin{array}{l}\text { Main role of private } \\
\text { health insurance }\end{array}$ \\
\hline United States & 35.1 & 72 & Primary \\
Netherlands & 15.2 & $28 / 64$ & Primary/Supplementary \\
France & 12.7 & 92 & Complementary \\
Germany & 12.6 & 18 & Primary/Supplementary \\
Canada & 11.4 & 65 & Supplementary \\
Ireland & 7.6 & 43.8 & Duplicatory \\
Australia & 7.3 & 44.9 & Duplicatory \\
Spain & 3.9 & $2.7 / 10.3$ & Primary/Duplicatory \\
\hline
\end{tabular}

Source: Private Health Insurance in OECD Countries (2004).

\subsection{The theoretical case for PSHI}

40. Countries introduce or expand the use of PSHI for three main reasons:

- A first advantage is expanding individual choice. Individuals can choose among providers, typically differing by premium levels and customer service. In addition, single insurers may offer choice across multiple products differing in terms of individuals' out-of-pocket expenditure and benefit package. Greater choice may allow individuals to satisfy more accurately their preferences. However, individual choice needs to be accompanied by mechanisms to support choice, including information standards and regulatory safeguards making the market competitive, attractive, and non-selective.

- Second, private insurers can spur innovation and flexibility. Health insurers may expose privately insured individuals to alternative approaches to health-care delivery, stimulate the development of more flexible policies, and investigate new ways to develop specific models of care. The right regulatory balance is again critical in this respect.

- Finally, PSHI may reduce cost pressures, both generally and in particular on public systems.

\subsection{Getting the framework right}

\subsubsection{Expanding individual choice and spurring innovation}

41. In practice, the scope to which insurers can tailor a package of health services to reflect individual choice is limited, partly by the costs of doing so (see below) but also because government regulations seek to ensure that high-risk individuals are not priced out of the market. 
42. In Australia, for example, regulation to foster cross-subsidisation from low-risk to high-risk groups includes community-rating requirements and, since 2000, the imposition of lifetime health cover. The former obliges health funds to charge the same premiums to insurees irrespective of risk, gender, or health status. The latter encourages early take-up of insurance policies by requiring health funds to apply the same base premiums, calculated at age 30, as long as individuals take out insurance cover before 30 and remain insured thereafter. Insurers can apply premium increases to individuals buying health coverage after age 30. In Ireland, too, there are legal requirements for community-rating, benefit packages, open enrolment, and lifetime cover.

43. The 1996 Swiss health insurance reform (LAMal) was designed to promote both greater solidarity and freedom of choice in basic mandatory health insurance. The reformed system improved equity through a combination of regulation (open enrolment, standard benefits and community rating of premiums) and financial incentives (financial equalisation across insurers of different risk structures and means-tested subsidies for low-income individuals). While the LAMal represented an improvement over the shortcomings of the previous regulatory regime, particularly in terms of equity, the experience of basic health insurance in Switzerland shows how difficult it is to make a system of regulated competition work in practice. The combination of historical differences in risk structures across insurers offering basic coverage, low migration rates due to consumers' reluctance to switch insurer, and only partially effective risk equalisation creates gains for insurers who 'cream skim’ good risks (Colombo 2001).

44. In order to increase risk-pooling for high-risk groups in the private health insurance market, the Dutch government regulates the provision of standardised contracts through the Health Insurance Access Act (WTZ). The government determines benefit coverage and the cost-sharing features of these policies. Criteria for eligibility to standardised contracts are also regulated. ${ }^{8}$ The government also controls the premiums charged on standard policies, which are kept much lower than the medical expenditures paid by insurers for those insurees. In order to ensure the viability of the private insurance market, privately insured individuals pay, in addition to their own insurance premiums, a solidarity contribution towards the cost of WTZ policies.

45. While standardised policies for high-risk groups promote access to coverage and solidarity across individuals of different health risk, the system presents some problematic features. Despite well-defined eligibility criteria, identifying high-risk individuals who can obtain standardised coverage is complex in practice. This poses the risk of an imperfect targeting of regulation. In addition, a balance between procompetitive and pro-solidarity regulation is difficult to achieve. By providing insurers with complete compensation for the higher cost of WTZ insurees, via the cost-sharing contributions paid by all other insurees, insurers do not face incentives to improve quality and efficiency of care provisions on standard contracts.

46. There are important differences between the group contracts and the less common individual contracts in the United States. These two types of policies tend to feature different pooling and pricing structures, as well as often offering different benefit packages. Individuals who do not have access to group insurance are greatly disadvantaged, as they have to buy cover (if they can afford it) at higher cost because of the greater administrative costs of dealing with individualised polices. Group policies spread risk across a larger, and usually relatively healthier, pool of people, and premiums tend to be community-rated within the group. The advantage of being insured under group contracts partly explains why the U.S. federal government facilitates access to group insurance for certain individuals who would otherwise have lost

8. Groups which are eligible include the over 65 year olds who were previously privately insured, high-risk individuals whose income is above the threshold for eligibility to public insurance, privately insured students, and others. About 14\% of privately insured individuals were covered by WTZ policies in 1998 (Gress et al., 2002). 
employer-sponsored coverage through the federal "COBRA" law (which enables continued membership to previous employers' schemes for a specified time period, provided individuals pay the full cost of the premiums, including the share previously paid by the employer).

47. Aside from these regulatory restrictions on the scope of private insurers to provide more choice in packages of medical insurance, it is also the case that sometimes a market has failed to develop, leaving consumers faced with a private sector monopoly or monopsony. After opening up to competition in 1994, the Irish private health insurance market is still dominated by the quasi-public Voluntary Health Insurance Board. ${ }^{9}$ Only one additional insurer, BUPA Ireland, has entered the market. Better definition of the status of the Voluntary Health Insurance Board and its interdependence with the Department of Health and Children, as well as the establishment of a pro-competitive system of risk equalisation across insurers, are among the key tasks facing Irish policy makers I the PHI field.

48. In sum, the scope for private insurers to offer different packages to reflect individual preferences has often been severely constrained by regulatory practices designed to expand the appeal of PSHI to groups who would otherwise find it too expensive. There is a genuine dilemma here: to be worthwhile, coverage of PSHI needs to be high, but the regulatory framework which ensures this undermines at least to some extent one of the main reasons for having PSHI in the first place.

\subsubsection{Cost-containment}

a)

Reducing the costs of provision

49. Insurers do not have a good track record in containing the cost of health services. In Australia, insurance premiums soared in 2002, forcing the government to enforce regulatory and monitoring interventions to ensure continued affordability of private care for PHI enrolees. Premium affordability is also becoming a greater concern in Ireland despite a pricing policy aimed at controlling premium inflation by keeping the fees of private treatments received in public hospitals below the full cost. Annual increases in premiums have been higher than the growth of the consumer price index without much impact on demand for PHI. However, a third of insurees view premiums as expensive, and over half of those noninsured are unwilling to pay private premiums, according to a recent report (Watson and Williams, 2001). As private hospital facilities become more widespread, concerns about the impact of higher prices of private facilities on premium inflation are also mounting.

50. Managed care was the favoured private-sector solution in the 1990s to promote cost savings in the United States. While such plans were initially successful, gains have proved to be temporary as a recent return to double-digit growth in health expenditure shows. Moreover, a backlash against the restricted choice of providers and care options in managed care makes the continuation of similar approaches less likely. Insurers have responded to consumers' dissatisfaction by seeking new innovative ways to control premium inflation. However, a growing reliance on demand-side approaches, like increasing insurees costsharing and decreasing benefit comprehensiveness, shifts the cost burden towards the enrolled, without addressing the root causes of the cost increase.

51. The post-1996 Swiss system established a mechanism of freedom to choose insurers whereby individuals can, twice per year, switch to any other insurer of their choice. The law is meant to stimulate choice-led competition on price-quality ratios, which is viewed as a tool to extract efficiency

9. The Voluntary Health Insurance Board was established in 1957 in the context of the failure of, and absence of, commercial companies from the market. 
improvements and cost savings from the health care system. However, as insurers are not free to contract with providers selectively and benefit packages are standardised, they have few incentives and levers to implement cost-reducing strategies. They tend rather to compete on administrative procedures and the selection of preferred risk.

52. In sum, the experiences of these five countries show that PSHI has not proved effective to date in achieving cost-containment. This disappointing result stems from a number of factors. First, administrative costs are lower in single-source health systems compared with systems with multiple competing insurers. Private health insurers charge premiums that absorb the costs of advertising, billing, and innovating products. There are also important transaction and information costs borne by individuals. Choosing or changing an insurer has considerable costs linked to comparing alternative options, understanding rules related to private contracts, and filing claims. Individuals are also exposed to financial risk and face the uncertainty of erroneous decisions: they need transparent information to become confident and aware about the product they are buying. Second, multiple competing insurers do not have monopsony bargaining power over the price, volume and quality delivered by service providers. Providers themselves face higher costs of dealing with multiple insurers, and transfer the cost into higher private fees, unless the contrary is explicitly regulated. Higher costs are then transferred by private insurers to the individual through higher premiums, making private coverage less affordable. Third, private insurers have incentives to shift the cost of high-risk patients or high-cost procedures to other payers, for example taxpayers. Where public and private delivery systems exist in parallel, private hospitals often concentrate on elective surgery and simple procedures, leaving emergency and urgent care to public providers.

\section{b) Reducing public expenditures}

53. PHSI has consequences for public finances. In many countries, including all five considered here, the take-up of PHSI has been subsidised by tax incentives. Tax advantages for the purchase of PHI benefit well-off taxpayers more than lower income groups. If only high-income groups buy the cover, the tax subsidy might not be welfare-enhancing, particularly if the cover includes non-medically necessary items. On the other hand, in those countries where PHSI runs parallel to a public system, there may be savings to the public budget from reduced direct outlays.

54. In Australia, a 30\% tax rebate, introduced in 1999, gives individuals a deduction on the full cost of their health insurance premiums, thus making the purchase of private coverage more economical (Hall et al., 1999). In Ireland, the tax relief on private health insurance premiums reduces premium cost by an estimated 32\% (Department of Health and Children 1999). Large tax advantages influence U.S. employers' decisions to sponsor health coverage for their employees. Both employees' and employers' taxable income is calculated excluding the cost of health coverage.

55. The amounts involved in these tax subsidies are not trivial and, as a result, they have been questioned. In Australia, evidence shows that the fiscal costs of the 30\% tax rebate might exceed cost savings in the public health system, suggesting that tax revenues could have been better spent if directly targeted to the public hospitals (Duckett and Jackson 2000). In the United States, Shiels and Haught (2004) estimate that exemptions for employer-provided health cover and other favourable tax treatments for health would result I forgone federal tax revenue of almost $\$ 190$ billion in 2004 , equivalent to around $1.7 \%$ of GDP

\subsection{Conclusion}

56. There is little doubt that private social health insurance has the potential to yield welfare gains by facilitating greater individual choice and innovation. However, it also presents risks. Private health 
insurance markets may fail to deliver social goals because of endemic market imperfections, for example information is asymmetrically distributed between insurers and individuals, and private insurers may compete on the selection of good risks rather than on efficiency and quality improvements. Regulation to remove some of the drawbacks of competitive private insurance markets has been implemented to different extents across OECD countries, in part mitigating the problems. But the price paid of following such an approach is to sharply reduce the scope for private providers to respond to individual wants and to innovate in the package of services they offer.

57. Furthermore, PSHI increases the administrative costs of the health care system. In theory, these might be offset by greater efficiency caused by pressures on providers to reduce costs, but these do not appear to have been realised to date. Given that PSHI does give rise to inequality in access to health care either because high-income groups buy such coverage in order to receive better or quicker treatment than other groups, or because the tax advantages given to stimulate take-up of insurance benefit high-income taxpayers more than low-income groups - there are also doubts about whether the public finance costs which are inherent in such a system are well-spent on redistributive grounds.

\section{Private social spending in practice: private pensions}

\subsection{The objectives of private pensions}

58. More and more countries are moving away from an almost exclusive reliance on public pensions toward mixed models of retirement income provision. Public pension schemes are being scaled down to reduce fiscal pressure and to increase space for contributions to private occupational and personal pension arrangements. In the foreseeable future, it is likely that a growing number of workers will be relying on private pension insurance as a source of income in old age. The policy reasons for this trend are riskdiversification and a wish to contain the level of compulsory contributions to public systems.

59. No country is envisaging moving fully from a PAYG programme to one which is fully-funded, if only because of difficulties in financing the transition between the schemes. Rather, the issue is whether there should be greater reliance on private provision and, if so, to what extent. For this to be feasible, policy makers must ensure that a sufficient number of workers actually benefit from private arrangements. Policies must aim at high coverage of such private contracts, and monitor whether private pensions intended to replace or supplement public arrangements are sufficient to prevent old-age poverty.

\section{$5.2 \quad$ Experience in $\mathrm{OECD}$ countries}

60. A recent OECD study (OECD 2001) which examined financial resources in retirement in nine Member countries, confirmed the trend towards a more diversified retirement income package. It showed that the mix of main income sources of older persons has been changing during past decades. The importance of income from work has been falling due to a strong trend towards early retirement, while the share of capital income has been growing as a result of more private pension arrangements and asset accumulation.

61. Analysis and assessment of private pension arrangements is complicated by the lack of consistent data. In particular, the most important social aspects of private pensions - coverage and adequacy - lack proper documentation. Often, the importance of private pensions is measured only by the level of financial assets accumulated in private funds (e.g., OECD 2002d). Apart from the fact that countries apply different definitions of private pensions, depending on the type of financial instrument used, assets data do not give any information on the extent of social protection offered through private pensions. Coverage data, 
however, often come from surveys. Workers are asked whether they are participating in a plan or whether they have done so in the past, unfortunately usually without any indication of contribution periods and entitlement levels. Efforts are underway at the OECD to improve data quality and collection procedures but currently there are only estimates, with no reliable measures available in the majority of countries.

\subsubsection{Coverage}

62. Private pension insurance comes in different forms: occupational pensions, which are administered at the company or branch level and exist as defined-benefit and defined-contribution plans, and personal pensions, which usually take the form of individual retirement accounts, but can also be any other type of tax-preferred retirement savings with a bank, an insurance company or other financial service providers. In most countries, occupational pension coverage is higher than personal pension coverage.

63. A number of countries (e.g., the Netherlands, Switzerland, Ireland, Australia, United Kingdom, and Sweden) have made private pensions an explicit component of their retirement income policy, either through occupational schemes, personal pension plans or a combination of the two. As a consequence, coverage rates of private pension insurance are relatively high in these countries. In some cases, participation in private pension arrangements is either compulsory or a basic element of collective bargaining, which explains coverage rates of $90 \%$ or more in the Netherlands, Switzerland and Sweden. Most of the high-coverage countries also encourage voluntary take-up of personal pensions and retirement savings through tax incentives.

64. But in a large number of OECD countries private pensions still play a minor role and are only gradually being promoted as a source of retirement income. These countries usually have large public PAYG pension systems with fairly generous replacement rates and opinion polls register high levels of public support for the existing structures. Additional private pension provision is thus considered less urgent and in some countries is even seen as a dangerous avenue, potentially undermining public systems and exposing the income security of workers in their old age to the fluctuations of the capital markets. Examples are France, Austria, Italy and Germany, though the latter two countries have recently reformed their systems and taken measures to encourage the take-up of occupational and personal pensions.

65. In Canada, Ireland, the United Kingdom and the United States, coverage of occupational pensions is promoted as desirable, but coverage rates are typically around $50 \%$ of the workforce, with personal pensions taking total coverage up to between 50 and $60 \%$ of employees (Chart 5). Left out are the more vulnerable groups in society, such as young unskilled employees, those working part-time and under fixed-term contracts (often women), employees of small companies and the self-employed. These groups are only explicitly addressed in those countries that already have high coverage, such as the Netherlands where the quasi-compulsory occupational pensions were recently extended to part-time workers. 
Chart 5. Participationin tax-favoured retirement income plans

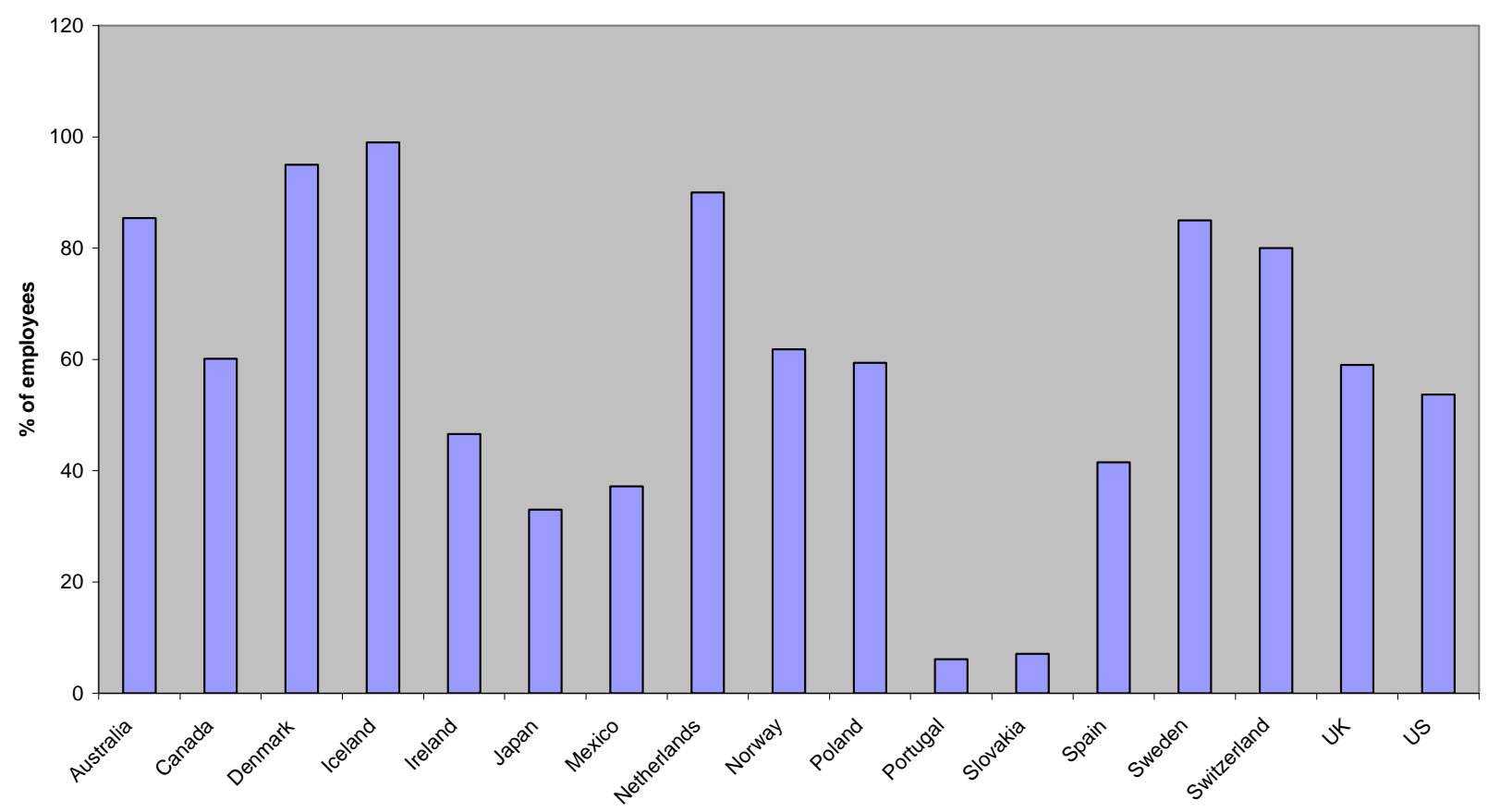

Source: Antolin et al., 2004.

66. Membership in personal pension plans is growing in most countries although coverage levels are still quite low. While participation in occupational plans is usually automatic or even obligatory for workers in a company offering such plans, take-up of personal pensions requires an active effort on the part of the worker to choose a plan. Governments are increasingly now informing their citizens of future pension entitlements by sending out regular pension statements; as people realise that public pensions will be lower than anticipated (even in the absence of further entitlement-reducing reforms, which can be safely predicted for many jurisdictions), more private provision will be made.

67. As with private health insurance, where private pensions are not mandatory, tax policies deductions or refundable tax credits - are frequently used to encourage workers to make their own provisions. Even after taking account of future taxes to be paid on tax exempt savings, these involve nonnegligible tax expenditures. Recent OECD estimates suggest that the tax concessions for pensions are worth over 1.7\% of GDP in Ireland, Australia and the United Kingdom, and over 1\% of GDP in Switzerland, Canada, the United States, Denmark, Iceland and the Netherlands (Antolin et al., 2004). Governments have found that such tax incentives are largely benefiting the richer groups of society. Individuals earning $200 \%$ or more of the average wage represent $13 \%$ of all employees in the United States, they account for around $20 \%$ of total participants in retirement savings plans and nearly $50 \%$ of total contributions, whereas their share of total salaries is $38 \%$. Similarly, in Canada, $13 \%$ of workers earn 2 times the average wage but form $26 \%$ of participants in retirement savings plans and account for $47 \%$ of contributions, compared to a share of total income of about 40\% (Antolin et al., 2004; CBO 2003).

68. Another problem results from the combination of minimum pensions or income guarantees and incentives to build up private pension entitlements. Often, low income workers have little incentive to save for retirement as their public minimum pension entitlement is reduced in line with the accrual of any 
personal savings. In the United Kingdom, recent reforms therefore introduced a pension credit to prevent this trap. In the future, retirement savings by low and modest-income earners above the level of the public pension will be rewarded through cash additions.

69. These examples show that introducing private pensions as a substitute or as a complement of public pension schemes without additional measures to ensure high coverage and integration into existing structures is unlikely to lead to satisfactory results. The usual way of encouraging take-up through tax incentives is often costly and too ineffective, or gives too large a subsidy to high-income groups. Compulsion is an option that many countries consider, but can risk forcing individuals to tie up their savings in inappropriately long-term investment.

\subsubsection{Adequacy}

70. The adequacy of private pension arrangements is crucial from a social policy perspective, especially if private pension insurance is to replace parts of pension benefits previously provided by public systems. But the adequacy of private provision is even more difficult to measure and assess than coverage. The level of future entitlements from private contracts is subject to a high degree of uncertainty. This is due to several factors:

- The trend towards more defined-contribution schemes. An increasing number of occupational pension schemes are moving from the defined-benefit type to defined-contribution plans. This means that workers' future pensions are impossible to determine in advance since they depend on uncertain investment returns. The same is true for personal pension plans, which are generally defined-contribution plans (unless they are taken out from the start as life insurance contracts with a defined annuity).

- Vesting rules. In most countries, private pension entitlements do not vest immediately which means that the worker does not own his or her pension rights until a certain period of employment with a company has elapsed. Workers who change employment earlier may lose all or part of their accrued pension rights. Losses can also occur when the accrued rights do not take full account of wage and price inflation until retirement.

- Portability of accrued rights. Not all countries have solved the problem of pension portability; even vested rights can be lost or reduced when workers move from one company or one country to another. As shown in Whitehouse (2003), even a relatively limited number of changes of employer over a working life can dramatically reduce expected pensions. If geographic and occupational mobility were to increase, as many commentators predict, future pension levels could become more difficult to estimate.

- Indexation. The long-term adequacy of private pension benefits also depends on the indexation both of pension rights and of pensions in payment. Rules for the adjustment of pension rights and payments to inflation vary greatly among OECD countries. Few countries require the full indexation of occupational pensions to prices and wages, most countries have some minimum rules but leave a great deal of discretion to the sponsoring companies.

71. Most OECD countries are addressing these problems and are putting policies in place to increase the adequacy and security of private pension arrangements. A good example for the protection of workers' rights is found in Switzerland where all private pension entitlements vest immediately and are fully portable from one plan to another (See Queisser and Vittas 2000; Queisser and Whitehouse 2003). Many other countries have introduced regulations that limit the maximum period before which benefits begin to 
accrue. Portability problems are also being addressed at an international level; harmonisation of tax treatment for personal pensions is a priority issue for the European Union, for example.

72. Partly as a result of the regulations necessary to address these problems, but also as an intrinsic part of any private pension system, there is great concern about the level of administrative costs. Experience with personal pensions and individual retirement accounts in many countries shows that the administrative costs of such plans can be so high as to reduce workers' retirement capital substantially (see, for example, Murthi, Orszag and Orszag 1999; James, Smalhout and Vittas, 2001; Whitehouse 2000; and Queisser 1998). Personal pensions are offered by a wide range of financial service providers who apply an equally wide and bewildering range of fees and conditions. Workers are often not aware of the price they are paying and thus of the extent to which administration costs will reduce future pensions.

73. The problem of high administrative costs is being addressed in different ways. In 2001, the United Kingdom introduced a new standardised product, the "stakeholder pension". This pension product will be offered by financial service providers and non-profit organisations, including trade unions. Members can stop and start contributions without penalty, and the administrative charges are capped at one $\%$ of assets. All employers are obliged to provide workers access to this product unless they already offer an occupational plan with immediate vesting or salary contributions into a personal pension plan. Take-up so far has been rather low. In part, this is because many of the target group already have a private pension (Disney et al,. 1999).

74. Other governments are trying to reduce costs by modifying the organisational structure of pensions or regulating the type of fees that can be charged. In Sweden, the new individual accounts are managed by a central public agency, which acts as an intermediary between workers and financial service providers. Workers can choose investment of funds from a wide range of options but their choices are communicated to financial service providers by the public agency. By severing the direct link between commercial providers and workers, the government is hoping to lower marketing expenses and thus administrative costs. Providers are also obliged to apply a scale of rebates on fees depending on charge levels and on the number and size of accounts they manage. Germany is applying a different approach in its new private pension system: providers are not allowed to charge administrative costs up-front; instead, costs must be amortised over a period of ten years.

75. Finally, it is pointless discussing adequacy if public policies to safeguard pension promises to workers are insufficient. The main instruments used by countries are funding requirements to guarantee the liquidity of defined-benefit plans, investment regulations to protect defined-contribution schemes, regulations addressing disclosure, transparency and reporting, as well as a reliable supervisory structure. The importance of regulation and supervision cannot be overestimated, as the well-known examples of private pension scandals show. ${ }^{10}$

10. Prominent examples include the Maxwell case and the pension mis-selling scandal in the United Kingdom and, more recently in the United States, the Enron case. Each of these cases represents a different area for policy action. In the Maxwell case, protection against fraud and mismanagement proved inadequate, leaving pensioners to bear the costs of illegal behaviour by the managers of the firm. In the mis-selling scandal, regulation of pension providers was lacking, leading to disreputable behaviour by financial service companies and their salespersons, encouraging people to take out private pensions when it was not in their interests to do so. In the Enron case, regulation of investment of pension assets was lacking, permitting the investment of pension assets in the stock of the sponsoring company, leaving contributors overlyvulnerable to the performance (and in this case, misbehaviour) of the firm. 


\subsection{Assessment}

76. In sum, coverage and adequacy of private pension arrangements are not easy to ensure. This is due to a fundamental dilemma: on the one hand, policy makers are trying to introduce more flexibility into existing pension systems by moving more responsibility into the private sector; on the other hand, coverage and adequacy of such private contracts cannot be ensured without a high degree of compulsion and regulation. Prescribing contribution levels, for example, helps to ensure adequacy but runs counter to the aim of increasing flexibility for employers and workers. This is precisely the same dilemma that faces those seeking to use private health insurance to overcome some of the rigidities of public systems, as discussed in the previous section.

77. Even the regulation of administrative costs and organisational structures may eventually turn against the interest of workers. Regulations may become excessively complex and increase the administrative burden for plan sponsors to a point where employers decide to stop offering occupational plans, or limit coverage only to higher-income workers as a policy to attract and retain qualified staff. There are signs that this stage has been reached in the United Kingdom, for example, with many companies closing down their occupational pension plans to new employees. Complex regulations can also affect personal pension plans; in many countries, workers need to hire pension consultants to understand the differences in conditions and fees of the various plans on offer. To strike the balance between proper regulation and protection of pension plan participants and a sufficient degree of flexibility in private provision represents a considerable challenge to policy makers, and it is arguably one to which no country has yet found an appropriate solution.

78. Furthermore, these tradeoffs partly undermine the underlying economic case for moving to a greater reliance on private pensions. As noted in Section 3, some advocates claim potentially very high rates of return from moving to private pension provision, because the rate of return on capital is so high. However, regulations seek to protect investors by reducing their exposure to risk (through imposing limits on investment in 'risky' assets and requiring investment in public sector debt, for example). Such regulations may well be necessary, both because it may be considered socially unacceptable that some unlucky individuals may have a very low rate of return on their pension investments, but also because a series of private pension scandals have left individuals in need of reassurance that private pensions are safe. Although necessary, such regulations do, however, mean that the difference in rates of return between 'risky' private sector and less risky public sector investments cannot be exploited fully, so the potential gains from greater use of private provision cannot be fully realised.

79. One promising approach is the use of target replacement rates in diversified systems. These targets refer to the overall income package, combining public and private pension benefits. Occupational defined-benefit plans are already integrated with public pensions in most countries (for example, in Canada, Finland, the Netherlands and Sweden - and to some extent in the United Kingdom and the United States - workers are often sent statements estimating their expected overall pension); often, the target replacement rate is part of labour negotiations; it is also influenced by tax rules, which limit deductibility to a combined maximum benefit from the public and private systems. For defined-contribution plans, however, integration is more difficult since the final benefit produced by such plans is subject to uncertainty.

\section{Private social spending in practice: care provision for children and the frail elderly}

80. The third set of examples are drawn from the direct provision of care by private (as opposed to public) providers. This raises a set of issues which are related to, but are different from, the previous examples, which referred to the issue of public versus private funding and insurance. Long-term care and 
child care are of growing importance - most obviously because of population ageing vastly increasing the numbers of frail elderly over the coming decades. The case of childcare is particularly interesting. It is believed by many governments that quality childcare provision can positively influence child development outcomes. Furthermore, the cost of childcare is often so high as to be a serious barrier to the labour force participation of mothers. As a higher labour force participation of mothers of young children is a policy objective in a number of countries, there has been much interest in the level of child-care provision (see OECD 2001c, 2002a).

81. Many countries have mixed public and private provision of care - a certain number of places in public institutions, with families free to purchase private provision if they can afford it. This section is not about the issue of how much finance for care comes from general taxation and how much falls directly on family budgets, but rather about whether public funds should go to financing direct public provision of care as opposed to subsidising families who may purchase care from private sector providers.

82. Whether child-care institutions and nursing homes should be public, private non-profit institutions or private firms is a cause of heated debate in many OECD countries. Being public or private matters for care providers for some of the same reasons as in other sectors of the economy: being at arms' length from political interests may allow more flexibility and help organisations focus more on the quality and cost of the service they provide. However, the profit motive of private firms may imply incentives to reduce costs which are too strong and may be counterproductive in care services.

83. Consequently, in "privatising" care services, OECD countries often aim for a mixture of institutional arrangements including non-profit organisations, private firms operating under regulation and public agencies gaining more flexibility and independence with more clearly specified objectives than previously. In this field, policy differs from the rather uniform movement towards private for-profit ownership of previously state-owned enterprises in sectors like manufacturing, banking, transport, telecommunication and energy.

84. In broad terms, other aspects than ownership may matter more by the way they affect the incentives facing service providers. ${ }^{11}$ Indeed, there is a broad movement in OECD countries towards introducing competition in care provision and allowing users more choice. It is important to understand that these are separate issues: the dynamism of competition among (public and private) providers and the flexibility for users getting more choice can be achieved while at the same time maintaining or raising the level of public funding - if that is what is politically preferred. The following sections review in more detail how competition and user choice is implemented in OECD countries in early childhood education and care and in long-term care for the elderly and disabled, distinguishing between those policies which require liberalisation of the market, and those which require private ownership.

\subsection{Early childhood education and care ${ }^{12}$}

85. Care provisions for children below compulsory school age are quite diverse, from pre-primary schools focused on learning through centre-based day care to informal family-based day care. The extent and form of public involvement varies across these different categories. For pre-primary schools, public funding is predominantly channelled through public institutions rather than via subsidies to parents purchasing services. Public institutions therefore account for a somewhat larger share of enrolments than private pre-primary schools and day-care centres in most OECD countries (Chart 6). For family-based day

11. See Lundsgaard (2002) for a more comprehensive discussion of these incentive mechanisms.

12. The description draws on OECD (2001c), Rostgaard and Fridberg (1998), Besharov and Samari (2000) and national sources. 
care, public funding is typically channelled through subsidies and tax credits, allowing users more choice. In practice, the degree of competition among suppliers of (partially) publicly funded early childhood education and care therefore depends not only on provision modes within each category but also on the relative weights of these different categories and on whether public funding levels provide a level playing field across categories. Direct public spending (not including tax credits) on early childhood education and care arrangements for children from three years to compulsory school age ranges up to a maximum of $1 \%$ of GDP (Lundsgaard, 2002). For 0-2 year olds, only a limited share are served in (partly) publicly funded institutions.

\section{Chart 6. Public and private institutions in early childhood education and care, 1999}

Share of children enrolled in pre-primary education and centre-based day care for children from 3 years

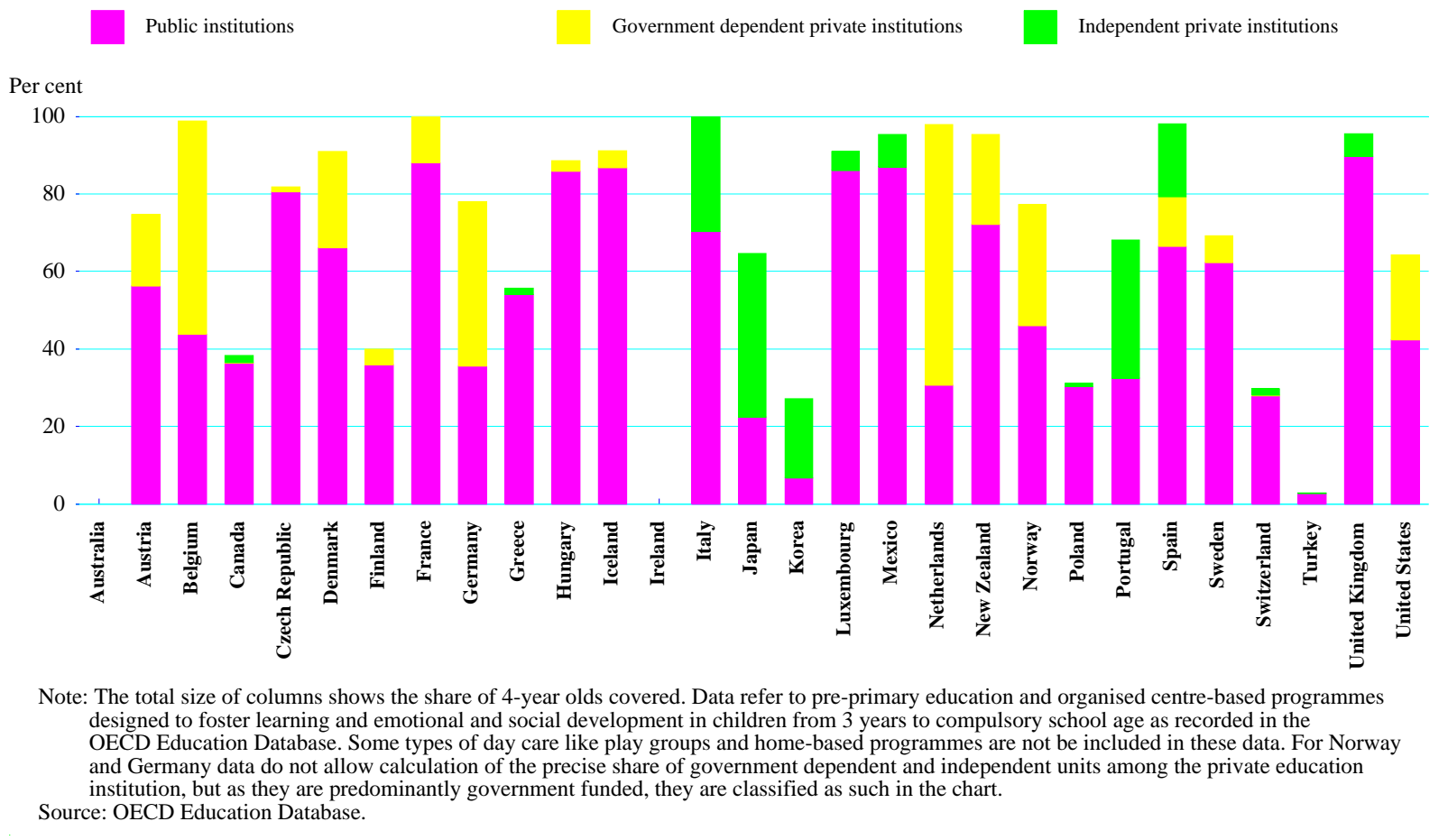

86. Comprehensive voucher-type reforms aimed at equalising the level of public funding per child across public and private institutions by channelling all public funding through users have been introduced in a few countries. Australia has implemented the most comprehensive reform, replacing the previous system based on grants to non-profit organisations and local governments. Now, public funding is distributed to families via the Child Care Benefit earmarked for childcare provided in Commonwealthapproved services. ${ }^{13}$ As a result, the public subsidy is equal across different institutional settings including for-profit and non-profit community-based day-care centres and to some extent family-based day care. The Netherlands and Norway are currently considering similar comprehensive reforms. In the United States, childcare vouchers have gained ground in federal family support programmes since the early 1990s. Whereas previously under this programme services were provided through direct funding to public institutions or through grants or contracts with selected private childcare institutions, recipients are now entitled to a voucher or cash benefit giving access to a wider range of care facilities.

13. Some operational grants still exist for institutions that are deemed part of the education sector and in some states. 
87. Tax credits and cash benefits conditioned on documented expenses for private childcare, however, resemble voucher systems and exist in many OECD countries (Lundsgaard, 2002). Tax credits and cash benefits are similar to vouchers in the sense that users can take the public funding they represent and spend it on a supplier of their own choice. In some cases these subsidies and tax credits are targeted at low-income and working families to improve their work incentives. This is the case in Australia, Canada, Germany, the United Kingdom and the United States. ${ }^{14}$ Indirect public funding through tax credits and other support for employer contributions to childcare expenses play a role in some countries including Belgium, Italy, the Netherlands and the United States. Where employers have some leverage over how their contribution is spent, this may help spur competition in childcare services.

88. Among private institutions, both non-profit organisations and private firms play a role. In the Netherlands and Belgium, publicly funded non-profit institutions account for more than half of enrolment in pre-primary education, while in other OECD countries public institutions dominate (Chart 6). In day care for the youngest children aged 0-2 years, the role of non-profit organisations receiving public funding is generally larger, e.g., the welfare associations in Germany and voluntary non-profit organisations in France. Looking at early childhood education and care as a whole, private firms play the largest role in Australia, where the share of day-care centres operated on a for-profit basis has grown during the 1990s to currently $73 \%$. In the United States, private firms supply 30\% of childcare services. For-profit childcare also exists in most European countries, playing a considerable role in Belgium, Italy, the Netherlands and Portugal, primarily for children under three years, while playing a more limited role in Finland and Norway.

\subsection{Long-term care for the elderly and disabled}

89. The provision of publicly-funded long-term care for the elderly and disabled is growing in OECD countries. Care may take place in public and private residential institutions or at home, and there are often also subsidies for the (informal) employment of personal attendants and tax credits and income support for relatives or friends acting as carers. At 3\% of GDP, public expenditure on long-term care is highest in the Scandinavian countries, reflected in a large share of old people living in nursing homes and other residential institutions, as well as a large share receiving help at home. Conversely, in southern Europe, Korea and Japan public and mandatory insurance expenditure is limited, as families retain a larger role in providing long-term care (Lundsgaard, 2002, OECD 2004).

90. Providing publicly funded long-term care in private nursing homes and residential institutions typically takes the form of subsidies resembling voucher systems - either reimbursing part of the fees paid by residents or paying a subsidy directly to the institution, based on the number of residents. Consequently, the effectiveness of competition hinges on the choice of institutions made by the individual elderly or their relatives. In Australia, the government has sought to control the prices charged by private residential institutions, making compliance with price controls a condition for receiving federal nursing home funding. Table 2 shows that private finance of long-term care expenditure is significant in many countries, and in Spain, the United States and Switzerland accounts for more than half of total expenditures. Furthermore, increasingly often, public finance goes to private providers. Hence, for example, over $80 \%$ of beds in institutions are private in the United Kingdom, Germany and the United States, and around half of institutional beds in the Netherlands, Canada and Ireland are privately run (OECD Health Data, 2003 and

14. But it is not the case in Denmark and Finland. In the latter countries a larger share of the youngest children are in publicly funded day-care institutions and therefore subsidies for private care may be regarded more as a competitive alternative to these institutions made available to all parents. The childcare benefit in Norway is not earmarked to purchase of private care and in practice works mainly as an income replacement while parents look after their own children. 
Rostgaand and Fridberg, 1998). The exceptions are Finland, Norway and Sweden, with only 10-15\% private residential institutions. While many private institutions are organised as non-profit organisations, for-profit firms operate a substantial share of institutions in Ireland, Portugal, New Zealand, the United Kingdom and the United States.

Table 2. Public and private expenditures on long-term care as a percentage of GDP, 2000

\begin{tabular}{|c|c|c|c|c|c|c|}
\hline & \multicolumn{3}{|c|}{ Public expenditure } & \multicolumn{3}{|c|}{ Private expenditure } \\
\hline & $\begin{array}{c}\text { Home } \\
\text { care }\end{array}$ & Institutions & Total & $\begin{array}{c}\text { Home } \\
\text { care }\end{array}$ & Institutions & Total \\
\hline Australia $^{1}$ & 0.31 & 0.57 & 0.88 & 0.08 & 0.26 & 0.34 \\
\hline Austria & 0.81 & 0.51 & 1.32 & & n.a. & \\
\hline Canada & 0.25 & 0.83 & 1.08 & 0.00 & 0.17 & 0.17 \\
\hline Germany & 0.42 & 0.50 & 0.93 & 0.05 & 0.17 & 0.22 \\
\hline Hungary & & & $<0.2$ & & & $<0.1$ \\
\hline Ireland & 0.19 & 0.33 & 0.52 & 0.00 & 0.10 & 0.10 \\
\hline Japan & 0.25 & 0.51 & 0.75 & & n.a. & \\
\hline Korea & $<0.1$ & $<0.1$ & $<0.2$ & & n.a. & \\
\hline Luxembourg & 0.15 & 0.37 & 0.52 & & n.a. & \\
\hline Mexico & & & $<0.1$ & & & $<0.1$ \\
\hline Netherlands & 0.56 & 0.78 & 1.34 & 0.05 & 0.02 & 0.07 \\
\hline New Zealand & 0.11 & 0.39 & 0.50 & 0.00 & 0.27 & 0.27 \\
\hline Norway $^{1}$ & 1.03 & 1.08 & 2.10 & & & 0.11 \\
\hline Spain $^{1}$ & 0.05 & 0.11 & 0.17 & 0.18 & 0.26 & 0.44 \\
\hline Sweden $^{1}$ & 0.82 & 2.06 & 2.89 & & & 0.14 \\
\hline Switzerland & 0.17 & 0.53 & 0.70 & 0.04 & 0.85 & 0.89 \\
\hline United Kingdom & 0.32 & 0.58 & 0.89 & 0.03 & 0.20 & 0.23 \\
\hline United States & 0.25 & 0.50 & 0.74 & 0.13 & 0.38 & 0.52 \\
\hline
\end{tabular}

Note: $1 . \quad$ Data is for age group 65+

Source: OECD (2004b).

91. Private organisations have traditionally played a strong role in providing long-term care services in a number of countries. This is probably even more the case for the emerging industry of home care providers than for the nursing home sector. Where churches and other charities had an important role in the past to provide care for the elderly, they still account for an important share of the industry (Austria, Germany). The same is the case for palliative care, which to varying degrees is integrated with long-term care services. 
92. A growing range of programmes provides allowances for the families of the elderly and disabled to retain their role as caregivers, or for the elderly and disabled to employ personal attendants of their own choice. Most are cash benefits without restrictions on their use, while others come close to being vouchers. The French scheme, introduced in 1997, allows the user to choose among different forms of care, including employing a personal attendant, with the restriction that family members can only be hired if currently unemployed. Likewise, the Finnish informal carer's allowance introduced in 1993 allows the user to employ a personal attendant, with the allowance being paid directly to that person. The German scheme introduced with the separate mandatory insurance for long-term care in 1995 allows users a choice from a menu of service provision and cash benefits.

93. Contracting with a limited number of private firms and non-profit organisations for the provision of publicly funded formal help at home is occurring in some countries, including the United Kingdom, Netherlands, Finland and Sweden. In some cases, contracts are awarded based on a standard competitive tendering process, where suppliers bid on the price. In other cases, contracts are made with a set of suppliers allowing users a choice of supplier as with a voucher scheme, but with an option for government to select among suppliers in subsequent contracting rounds, thereby adding to the competitive pressure on suppliers. Supplying formal help at home through public institutions nevertheless remains the dominant mode of service provision in the Nordic countries as well as the United Kingdom.

94. In the institutional care sector, the role of a range of private providers, of both profit and non-forprofit associations, has been strengthened recently in countries as they strive for greater competition among providers as an interim goal with the ultimate objective being to achieve both more choice from the side of users of these services, and more responsive and better quality services. For example, in Germany, the political decision to establish a universal public long-term care insurance was "packaged" with the regulation that the "new" money for home care services would create a growing and competitive market for home care services and there is an explicit rule that providers that newly enter the market have to be private organisations.

\subsection{Assessment of outcomes from competition and user choice in care services}

95. Unfortunately, there are few studies assessing the outcomes from introducing competition and user choice in care services, and therefore this assessment can only be indicative. Nevertheless, the following conclusions often appear in the experience of OECD countries:

- User choice is quite effective at focusing the attention of care providers on the different needs of individual users and this flexibility makes users more satisfied. Competition and less static funding schemes may also facilitate a swifter reallocation of activity and capacity adjustment in response to changing demand and care needs. One striking recent example in childcare comes from Australia, where there has been a move to subsidising purchasers rather than providers of care. As a result, more providers are now flexible in their openings hours. Furthermore, some are much less likely to insist on parents buying full weeks of care, instead allowing parents to buy care on an hourly or daily basis - very important to many parents, given the preponderance of part-time work and flexible working hours in the Australian labour market.

- Competition and funding schemes based on activity and outcomes are reported by managers to increase the cost-awareness of care providers. However, shifts to activity-based funding have typically been implemented in ways that did not cut down unit costs. 
- Subsidising informal long-term care by allowing users to employ a friend or relative as a personal attendant, rather than receiving care from an agency, is very popular among the elderly and disabled, as it increases flexibility in terms of when and how to receive care as well as resolving concerns about the quality of care provided. Similarly in child care, employing a trusted friend or relative may be a way of circumventing the information asymmetry making it difficult for the parents or relatives to monitor the quality of care, when they are away. However, concerns have arisen about the employment conditions of the personal attendants. Furthermore, the public expenditure consequences of reimbursing what was previously a gift arrangement may be too large to contemplate.

96. Note that most of these effects come from competition, not necessarily private ownership. However, it is difficult to imagine such competition without opening the market to new private sector entrants, be they for-profit or otherwise. The key challenge - as with health care insurance - appears to lie in developing the appropriate regulation of markets for care services. In telecommunications, transport and energy sectors, a lot has been learned over the latter decades about the crucial regulation of network access, where and where not to apply price regulations, etc. Care markets and the necessary regulation can be equally complex, and it is a high priority for countries to evaluate and draw the lessons from on-going reforms in this sector.

\section{Conclusions}

97. The claims and assumptions that are made by those seeking greater reliance on the private sector for the provision of social protection are many and varied. This variety confuses discussions. It is important to be clear about just what is the case for private provision in each particular policy area. Is it to shake-up a moribund public sector administration and deliver social services more effectively at lower cost? Is it to provide more consumer choice? Is it to promote more flows through the financial markets, either to increase economy-wide investment or to stimulate shareholder activism and investment efficiency? All these objectives need not be compatible with one another in any particular country at any point in time, and so generalised conclusions are not straightforward.

98. It is right to be cautious about many of the sweeping assertions that are often made about the economy-wide effects that might result from a greater reliance on the private sector in financing and delivering social protection. Whilst it is true that social programmes do utilise a substantial proportion of the output of economies, merely moving them to the private sector does not magically reduce 'the burden' of such expenditures. People want health care, childcare, care for elderly relatives, insurance against income loss, adequate incomes in retirement: they will devote resources to them, if not through the tax system, then through private sector alternatives. If governments provide too much or too little social protection, or the wrong kinds of it, or provide it inefficiently, or finance it using a tax system which unnecessarily damages the economy, there will be genuine economic gains from moving social provision from the public to the private sector. In each case, private provision may help address structural problems and may stimulate growth. But it is equally true that there are other routes to achieving such goals. Often, a reformed public system could address them and a badly-designed move towards greater private provision could perpetuate them.

99. Some clarity over objectives - and realism about what can be achieved - is required when considering the structure of social protection. The selected examples from recent OECD country experiences with private health insurance, care for children and the elderly, and private pension provision, lead to three main conclusions. 
100. Opening provision to a diversity of providers has often promoted more choice and innovation. There does seem to be a strong demand for choice in social protection. In childcare, private providers may be more flexible about opening times, charging structures and even philosophies of early childhood development. Elderly people often want to be cared for by people they know and trust. Individuals do want some flexibility over the amounts they save for retirement and their health care coverage. Relying on the public sector to provide more choice is theoretically possible, of course, if managers were given more flexibility and schemes restructured. But in practice, such diversity is more likely to come from the private sector, be it for-profit or otherwise.

101. Efficiency gains have often been limited. Despite the previous point, it is nevertheless true that increased use of private provision has shown little sign to date of leading to major cost savings for the provision of a given level of social protection. There are four main reasons for this disappointing outcome, which apply to different extents across the various areas and countries considered:

- In order to ensure that high-risk individuals are not priced out of the private health insurance market, regulation requires cross-subsidisation from some groups to others. This reduces the possibility of getting more diversity in choice, and reduces the extent to which costcompetition can take place.

- It is very expensive to manage individual accounts. This means that even private providers prefer group contracts in health or occupational pension systems. But individual choice is inevitably restricted by this route. Where individual accounts are used, the resulting high administrative costs do reduce the attraction of taking up such opportunities.

- There are often good reasons why particular services were publicly-provided in the first place. Informational asymmetries (how good is this childcare which I cannot personally monitor, or this health care package which I am not technically able to assess?) and myopia (I'm only 20: why should I save for my retirement?) are addressed by the public sector offering a guarantee of quality and adequacy, in return for the individual giving up the ability to exercise choice. Regulations have been designed to guarantee the quality of private sector provision - minimum ratios of carers to children; the package of health services covered; minimum contribution/benefit requirements for pensions. But these regulations, in turn, reduce the scope for innovation and competition.

- In order to stimulate take-up of private provision, governments often offer significant fiscal incentives. Quite apart from the distributional effects of such measures (see below), the fiscal costs have sometimes been sufficiently large to eliminate the budgetary gains of reducing direct expenditures. Tax breaks aimed at stimulating private protection arrangements often concern pension plans, e.g., by tax exemptions for contributions to these plans and/or tax relief for the investment income of capitalised pension funds. Available estimates indicate that such tax breaks can be significant; ranging between 1 to $2.5 \%$ of GDP in the Netherlands, the US and the UK (Adema, 2001).

102. This is a disappointing list, but it should not be seen as the final word on the efficiency issue. At the moment, the regulatory frameworks for private health insurance, private pensions and the provision of care services do not permit some of the efficiency gains that might be hoped for. It should be remembered that much the same could have been said about the private provision of telecommunications or buses in the early years of their privatisation. More work is needed in order to get the regulatory framework for social provisions right, but there is no particularly reason for thinking that this is necessarily impossible. 
103. The distributional aspects of private provision have not always been adequately addressed. A change towards more private provision, even if more economically efficient, may not be socially acceptable if it has major distributional effects. Governments want to redistribute from the healthy to the sick; from childless households to those with children; from working households to jobless households; even from the rich to the poor. While the fact that badly-functioning public provision may also lead to unequal distribution of benefits and services (e.g., waiting lists in public health systems) is often ignored, nevertheless there is suspicion that private provision will favour the rich, and this objection needs to be addressed.

104. One possible response is explicitly to take redistribution out of the social programme and to rely on the tax system rather than the benefit system to ensure that the equity goals of society are achieved. Indeed, the fact that the tax systems which are used to finance social expenditures are quite progressive is ultimately responsible for much of the interpersonal redistribution of income in many welfare systems (see Förster and Pearson, 2002). However, tax systems themselves may be under pressure to move in the opposite direction. Marginal tax rates on capital or on high earnings have fallen in recent years, either reflecting or (more likely) anticipating pressures on internationally-mobile tax bases as globalisation of production continues.

105. Furthermore, the tax reliefs given to encourage take-up of private pensions and private health insurance are worth more to high-income groups than low-income groups, precisely because the former have higher marginal tax rates. As a result, for example, redistribution in private health care plans in the US largely occurs within employer-sponsored health care plans, implicitly transferring expenditures from the healthy to the ill. The sizeable tax breaks provide large incentives to employers to provide health benefits, but are themselves regressive in impact. Similarly, since low-income earners are least likely to participate in private pension plans, and, if they do, for relatively small amounts, they are likely to benefit least from tax advantages.

106. In sum, experience of private provision of social protection is mixed. There are cases in health, pensions and care services where some gains have been made by use of private provision, particularly in promoting more individual choice over the form of protection. But for greater gains to be made, two main areas need more attention from policymakers. First, there is a need to develop forms of regulation which protect individuals from scandals such as Maxwell and Enron and which guarantee them a decent level of health care, child care or pension, but which also permit greater flexibility and competition between providers. Second, there is a need to be more inventive in ensuring that a move to private financing and provision of social benefits does not just benefit the rich. In the case of childcare and long-term care, the use of voucher-type systems or carefully targeted benefit systems has extended the benefits more widely, but for both medical care and pensions, the use of the tax system as the principal means of promoting takeup leads to a natural bias towards richer groups.

107. The import of these conclusions is that private financing and provision of social benefits is not a magic wand; waving it in the social protection field will not mean that the economy and voters will be freed from some great deadweight that has been dragging them down. Nevertheless, we can conclude that the private sector can sometimes deliver either a slightly cheaper, slightly more varied or slightly more flexible system of social protection. For those governments and electorates which are inclined to rely a bit more on the private sector to provide social protection, we have highlighted some important issues that need to be addressed. 


\section{REFERENCES}

ADEMA, W. and M. LADAIQUE (2005), “Net Social Expenditure 3rd Edition”, OECD Social, Employment and Migration Working Papers, OECD, forthcoming (http://www.oecd.org/els/workingpapers).

ADEMA, W. (2001), “Net Social Expenditure $2^{\text {nd }}$ Edition”, Labour Market and Social Policy Occasional Papers, No. 52, OECD, Paris.

ADEMA, W. and M. G. K. EINERHAND (1998), “The Growing Role of Private Social Benefits” Labour Market and Social Policy Occasional Papers, No. 32, OECD, Paris.

ARJONA, R, M. LADAIQUE, and M. PEARSON (2001), “Growth, Inequalities and Social Protection”, Labour Market and Social Policy Occasional Papers, No. 51, OECD, Paris.

ATKINSON, A.B. (1999), The Economic Consequences of Rolling Back the Welfare State, The MIT Press: Cambridge.

BASSANINI, A. and S. SCARPETTA (2001) 'The driving forces of economic growth: panel data evidence for the OECD countries’, OECD Economic Studies no. 33, 2001/2, pp. 9-56.

BESHAROV, A. and N. SAMARI (2000), "Child-care vouchers and cash payments”, in C.E. Steuerle, V.D. Ooms, G.E. Peterson and R.D. Reischauer (eds.), Vouchers and the provision of public services, Brookings Institution Press, Washington, DC.

BLANK, R. M. (1999) "When can public policy markers rely on private markets? The effective provisions of social security”, NBER Working Paper 7099, April 1999.

CBO (2003), Utilisation of tax incentives for retirement saving, Washington D.C.

COLOMBO, F. (2001). "Towards More Choice in Social Protection? Individual Choice of Insurer in Basic Mandatory Health Insurance in Switzerland”, Labour Market and Social Policy Occasional Papers, No. 53, OECD, Paris.

DEPARTMENT OF HEALTH AND CHILDREN (1999). White paper. Private Health Insurance. Government of Ireland.

ANTOLIN, P., DE SERRES, A. and DE LA MAISONNEUVE, C. (2004) "Long-term budget implications of tax favoured retirement plans” OECD Economics Department Working Paper no. 393.

DISNEY, R., EMMERSON, C. and TANNER, S. (1999) Partnership in pensions: an assessment. Commentary no. 78. Institute for Fiscal Studies, London.

DUCKETT, S. and JACKSON, T.J. (2000). "The new health insurance rebate: an inefficient way of assisting public hospitals”. Medical Journal of Australia, No. 172, pp. 439-442.

EBRI (2001), “Employment-Based Health Benefits: Trends and Outlook”, Employee Benefit Research Institute, Issue Brief Number 233, May 2001, Washington DC. 
FELDSTEIN, M, and SAMWICK, A. 1998. "Two Percent Personal Retirement Accounts: Their Potential Effects on Social Security Tax Rates and National Saving.” National Bureau of Economic Research, Working Paper No. 6540. Cambridge, Mass.: NBER

FÖRSTER, M. and PEARSON, M. (2002), "Income distribution and poverty in the OECD area: trends and driving forces”, OECD Economic Studies, No. 34, pp. 7-40

GENAKOPOLOS J., O. MITCHELL, and S. ZELDES (2000), "Would Privatised Social Security System Really Pay a Higher Rate of Return”, NBER Working Paper 6713, May 2000.

GRESS, S., OKMA, K. AND WASEM, J. (2002). "Private Health Insurance in Social Insurance Countries: Market Outcomes and Policy Implications”, Discussion paper 01/2002. Greiswald University.

HALL, J. DE ABREU LOURENCO, R. AND VINEY, R. (1999), “Carrots and Sticks - The fall and fall of private health insurance in Australia”, Health Economics, No. 8, pp. 653-660.

JAMES, E., J. SMALHOUT and D. VITTAS (2001) 'Administrative costs and the organisation of individual account systems: a comparative perspective’, in Holzmann R. and Stiglitz, J. (eds.), New ideas about old age security,. World Bank, Washington.

KALISCH, D.W., T. AMAN, and L.A. BUCHELE (1998), "Social and Health Policies in OECD Countries: A Survey of Current Programmes and Recent Developments”, Labour Market and Social Policy Occasional Papers, No. 33, OECD, Paris.

KAM, C.A. de and J. OWENS (1999), "Financing Social Protection in the 21st Century", in: Finnish Ministry of Social Affairs and Health, Financing Social Protection in Europe, Helsinki, pp. 175-203.

LEAHY, M., S. SCHICH, G. WEHINGER, F. PELGRIN and T. THORGEIRSSON, (2001) 'Contributions of financial systems to growth in OECD countries’, Economics Department Working Paper No. 280, OECD, Paris.

LUNDSGAARD, J. (2002), “Competition and efficiency in publicly funded services”, OECD Economic Studies , No. 35, pp. 79-128.

MINISTRY OF HEALTH, WELFARE AND SPORT (2002). A question of demand. Outline of the reform of the health care system in the Netherlands. The Hague: MOHW

MOSSIALOS, E. AND THOMSON, S. (2001). Voluntary health insurance in the European Union. Report prepared for the Directorate General for Employment and Social Affairs of the European Commissions, 27 February 2002.

MURTHI, M., J.M. ORSZAG and P.R. ORSZAG (2001), 'Administrative costs under a decentralized approach to individual accounts: lessons from the United Kingdom' in Holzmann R. and Stiglitz, J. (eds.), New ideas about old age security,. World Bank, Washington.

NICHOLS, L.M. (2002). Can Defined Contribution Health Insurance Reduce Cost Growth? EBRI Issue Brief Number 246, June 2002.

OECD (1998), Harmful Tax Competition, An Emerging Global Issue, Paris.

OECD (1999), A Caring World, the New Social Policy Agenda, Paris.

OECD (2001), OECD Social Expenditure Database, 1980-1998, $3^{\text {rd }}$ edition, (CD-ROM), Paris.

OECD (2001a), Ageing and Income, Financial Resources and Retirement in 9 OECD countries, Paris. 
OECD (2001b), Revenue Statistics, 1965 - 2000, Paris.

OECD (2001c), Starting strong: Early childhood Education and Care, Paris.

OECD (2001d), "Fiscal implications of ageing: projections of age-related spending”, OECD Economic Outlook, No. 69, June, pp. 145-167.

OECD (2001e), OECD Economic Studies, No. 32.

OECD (2002), Economic Outlook, No 71, June, Paris.

OECD (2002a), Babies and Bosses, Reconciling Work and Family life in Australia, Denmark and the Netherlands, Paris.

OECD (2002b), Taxing Wages, 2000 - 2001, Paris.

OECD (2002c), Tax Treaties and Harmful Tax Competition, Paris, forthcoming.

OECD (2002d) Insurance Statistics Yearbook, 1993-2000 - 2002 edition. OECD, Paris.

OECD (2002f) OECD Economic Outlook, no. 71

OECD (2004), OECD Social Expenditure Database, 1980 -2001, Paris, forthcoming (http://www.oecd.org/els/social/expenditure).

OECD (2004a), Economic Outlook, No 75, June, Paris.

OECD (2004b) Long-term Care for Older People. OECD, Paris.

QUEISSER, M (1998) The second generation pension reforms in Latin America, OECD Development Centre Studies.

QUEISSER M. AND VITTAS, D (2000) 'The swiss multi-pillar pension system: the triumph of common sense?’ World Bank Working Paper.

QUEISSER, M. AND E. WHITEHOUSE (2003). "Individual choice in the social protection: the case of Swiss pensions,” OECD Social, Employment and Migration Working Papers, No. 11, Paris.

ROSTGAARD, T. and T. FRIDBERG (1998) "Caring for children and older people - a comparison of European policies and practices”, The Danish National Institute of Social Research, Copenhagen.

SHEILS, J. and HAUGHT, R. (2004), “The cost of tax-exempt health benefits in 2004”, Health affairs.

TOLLEN, L. AND CRANE, R.M. (2002). A Temporary Fix? Implications of the Move Away From Comprehensive Health Benefits. EBRI Issue Brief, No. 244, April 2002.

WATSON, D. AND WILLIAMS, J. (2001). Perceptions of the quality of health care in the public and private sectors in Ireland. Dublin: The Economic and Social Research Institute.

WHITEHOUSE, E. (2000) 'Administrative charges for funded pensions: an international comparison and assessment', Pension Reform Primer Series, Social Protection Discussion Paper no. 0016, World Bank, Washington.

WHITEHOUSE, E (2003), “The value of pension entitlements: a model of nine OECD countries”, OECD Social, Employment and Migration Working Papers, No. 9, Paris. 


\section{OECD SOCIAL, EMPLOYMENT AND MIGRATION WORKING PAPERS}

Most recent releases are:

No. 22 INCOME DISTRIBUTION AND POVERTY IN OECD COUNTRIES IN THE SECOND HALF OF THE 1990S (2005)

Michael Förster and Marco Mira d'Ercole

No. 21 DESIGN CHOICES IN MARKET COMPETITION FOR EMPLOYMENT SERVICES FOR THE LONGTERM UNEMPLOYED (2004) Ludo Struyven

No. 20 BENEFIT COVERAGE RATES AND HOUSEHOLD TYPOLOGIES: SCOPE AND LIMITATIONS OF TAX-BENEFIT INDICATORS (2004) Herwig Immervoll, Pascal Marianna and Marco Mira D’Ercole

No. 19 AVERAGE AND MARGINAL EFFECTIVE TAX RATES FACING WORKERS IN THE EU. A MICROLEVEL ANALYSIS OF LEVELS, DISTRIBUTIONS AND DRIVING FACTORS (2004) Herwig Immervoll

No. 18 INDICATORS OF UNEMPLOYMENT AND LOW-WAGE TRAPS (Marginal Effective Tax Rates on Employment Incomes) (2004)

Giuseppe Carone, Herwig Immervoll, Dominique Paturot and Aino Salomäki

No. 17 TAKE-UP OF WELFARE BENEFITS IN OECD COUNTRIES: A REVIEW OF THE EVIDENCE (2004) Virginia Hernanz, Franck Malherbet and Michele Pellizzari

No. 16 THE SWEDISH ACTIVITY GUARANTEE (2004) Anders Forslund, Daniela Froberg and Linus Lindqvist

No. 15 LOW FERTILITY RATES IN OECD COUNTRIES: FACTS AND POLICY RESPONSES (2003) Joëlle Sleebos

No. 14 NATIONAL VERSUS REGIONAL FINANCING AND MANAGEMENT OF UNEMPLOYMENT AND RELATED BENEFITS: THE CASE OF CANADA (2003) David Gray

No. 13 THE COMPETITIVE MARKET FOR EMPLOYMENT SERVICES IN THE NETHERLANDS (2003) Ludo Struyven and Geert Steurs

No. 12 TOWARDS SUSTAINABLE DEVELOPMENT: THE ROLE OF SOCIAL PROTECTION (2003) MarCo Mira d'Ercole and Andrea Salvini

No. 11 INDIVIDUAL CHOICE IN SOCIAL PROTECTION: THE CASE OF SWISS PENSIONS (2003) Monika Queisser and Edward Whitehouse

No. 10 IMPROVING WORKERS' SKILLS: ANALYTICAL EVIDENCE AND THE ROLE OF THE SOCIAL PARTNERS (2003) Wooseok Ok and Peter Tergeist

No. 9 THE VALUE OF PENSION ENTITLEMENTS: A MODEL OF NINE OECD COUNTRIES (2003) Edward Whitehouse

No. 8 FINANCIAL RESOURCES AND RETIREMENT IN NINE OECD COUNTRIES: THE ROLE OF THE TAX SYSTEM (2003) Edward Whitehouse and Gordon Keenay

No. 7 THE IMPACT OF PARENTAL LEAVE ON MATERNAL RETURN TO WORK AFTER CHILDBIRTH IN THE UNITED STATES (2003) Sandra L. Hofferth and Sally C. Curtin

Recent available working papers can be found on the OECD website: www.oecd.org/els/workingpapers.

Other series of working papers available from the OECD include: OECD HEALTH WORKING PAPERS 
DELSA/ELSA/WD/SEM(2005)2

\section{RECENT RELATED OECD PUBLICATIONS:}

SOCIETY AT A GLANCE: OECD Social Indicators 2005

BENEFITS AND WAGES: OECD Indicators 2004

BABIES AND BOSSES: Reconciling Work and Family Life, Volume 3, New Zealand, Portugal, Switzerland (2004)

OECD EMPLOYMENT OUTLOOK (2004)

REFORMING PUBLIC PENSIONS: SHARING THE EXPERIENCES OF TRANSITION AND OECD COUNTRIES (2004)

ASSET BUILDING AND THE ESCAPE FROM POVERTY: A NEW WELFARE POLICY DEBATE (2003)

MANAGING DECENTRALISATION: A NEW ROLE FOR LABOUR MARKET POLICY (2003)

COMBATING CHILD LABOUR: A REVIEW OF POLICIES (2003)

AGEING AND EMPLOYMENT POLICIES - SWEDEN (2003)

AGEING AND EMPLOYMENT POLICIES - BELGIUM (2003) (French version only with Executive summary in English)

BABIES AND BOSSES: Reconciling Work and Family Life, Volume 2, Austria, Ireland and Japan (2003)

A DISEASE-BASED COMPARISON OF HEALTH SYSTEMS - What is Best and at What Cost? (2003)

TRANSFORMING DISABILITY INTO ABILITY: Policies to Promote Work and Income Security for Disabled People (2003)

HEALTH AT A GLANCE: OECD Indicators (2003)

BABIES AND BOSSES: Reconciling Work and Family Life, Volume 1, Australia, Denmark and the Netherlands (2002)

PRIVATE FINANCE AND ECONOMIC DEVELOPMENT (2003)

ENTREPRENEURSHIP AND LOCAL DEVELOPMENT: PROGRAMME AND POLICY RECOMMENDATIONS (2003)

THE NON-PROFIT SECTOR IN A CHANGING ECONOMY (2003)

TRENDS IN INTERNATIONAL MIGRATION: SOPEMI (2003)

SOCIETY AT A GLANCE (2002)

TOWARDS ASIA'S SUSTAINABLE DEVELOPMENT - The Role of Social Protection (2002)

MEASURING UP: IMPROVING HEALTH SYSTEMS PERFORMANCE IN OECD COUNTRIES (2002)

AGEING AND INCOME: Financial Resources and Retirement in 9 OECD Countries (2001)

For a full list, consult the OECD On-Line Bookstore at www.oecd.org, or write for a free written catalogue to the following address:

OECD Publications Service

2, rue André-Pascal, 75775 PARIS CEDEX 16

or to the OECD Distributor in your country 